\title{
Calibration of Empirical Equations for Estimating Reference Evapotranspiration in Different Climates of Iran
}

\author{
Saeed Sharafi ( $\sim$ s-sharafi@araku.ac.ir) \\ assistant professor at Arak University, Arak, Iran \\ Mehdi Mohammadi Ghaleni \\ Arak University, Arak, Iran.
}

\section{Research Article}

Keywords: Calibration, ETref Estimation, Scatter Index, Water Resource, Zonation

Posted Date: March 22nd, 2021

DOl: https://doi.org/10.21203/rs.3.rs-329501/v1

License: (c) (1) This work is licensed under a Creative Commons Attribution 4.0 International License.

Read Full License 


\title{
Calibration of empirical equations for estimating reference evapotranspiration in different climates of Iran
}

\author{
${ }^{* 1}$ Saeed Sharafi, ${ }^{2}$ Mehdi Mohammadi Ghaleni
}

1. Assistant Professor, Department of Environment Science and Engineering, Arak University, Arak, Iran. 2. Assistant Professor, Department of Water Science and Engineering, Arak University, Arak, Iran.

Corresponding author: Saeed Sharafi

Corresponding email: s-sharafi@araku.ac.ir

Telefax: $+\underline{+988632623702}$

\begin{abstract}
The accurate estimation of reference evapotranspiration ( $\left.\mathrm{ET}_{\mathrm{ref}}\right)$ is a crucial component for modeling hydrological and ecological cycles. The goal of this study was the calibration of 32 empirical equations used to determine $\mathrm{ET}_{\text {ref }}$ in the three classes of temperature-based, solar radiation-based and mass transfer-based evapotranspiration. The calibration was based on measurements taken between the years 1990 and 2019 at 41 synoptic stations located in very dry, dry, semidry and humid climates of Iran. The performance of the original and calibrated empirical equations compared to the PM-FAO ${ }_{56}$ equation was evaluated based on model evaluation techniques including: the coefficient of determination $\left(\mathrm{R}^{2}\right)$, the root mean square error (RMSE), the average percentage error (APE), the mean bias error (MBE), the index of agreement (D) and the scatter index (SI). The results show that the calibrated Baier and Robertson equation for temperature-based models, the Makkink equation for solar radiation-based models and the Penman equation for mass transfer-based models performed better than the original empirical equations. The calibrated equations had, respectively, an average $\mathrm{R}^{2}=0.73,0.67$ and 0.78 ; $\mathrm{RMSE}=35.14,35.02$ and $30.20 \mathrm{~mm}^{2}$ year $^{-1}$; and $\mathrm{MBE}=-$ 5.6, -3.89 and $2.57 \mathrm{~mm}_{\text {year }}{ }^{-1}$. The original empirical equations had values of average $\mathrm{R}^{2}=0.60,0.37$ and 0.65 ; RMSE $=68.34,66.98$ and $52.62 \mathrm{~mm}_{\text {year }}{ }^{-1}$; and MBE=-5.75, 4.26 and $8.99 \mathrm{~mm}^{2}$ year $^{-1}$, respectively. The calibrated empirical equations for very dry climate (e.g. Zabol, Zahedan, Bam, Iranshahr and Chabahar stations) also significantly reduced the SI value from SI $>0.3$ (poor class) to $\mathrm{SI}<0.1$ (excellent class). Therefore, the calibrated empirical equations are highly recommended for estimating $\mathrm{ET}_{\text {ref }}$ in different climates.
\end{abstract}

Keywords: Calibration, $\mathrm{ET}_{\text {ref }}$ Estimation, Scatter Index, Water Resource, Zonation

\section{Introduction}

The estimation of reference evapotranspiration $\left(\mathrm{ET}_{\mathrm{ref}}\right)$ by using hydrological equations can be helpful in agriculture sectors (Celestin et al. 2020; Ndiaye et al. 2020). It has a key role in the management of water resources and the determination of crops' water demands (Berti et al. 2014; Ferreira et al. 2019). The most accurate evaluation of $\mathrm{ET}_{\text {ref }}$ is computed by the lysimeter method, but this method has high costs and requires complex instruments (Ahooghalandari et al. 2016; Ahooghalandari et al. 2017). Therefore, alternative techniques for indirect estimation of $\mathrm{ET}_{\text {ref }} \mathrm{Were}$ developed based on empirical models, including temperature-based, solar radiation-based and mass transfer-based models.

In contrast, the $\mathrm{FAO}_{56}$ Penman-Monteith (PM-FAO $\left.{ }_{56}\right)$ equation is the standard combinationbased model used to estimate the $\mathrm{ET}_{\text {ref }}$ in different climates and at different time scales (Güçlï et al. 2017; Saggi and Jain 2019; Shiri et al. 2019; Ndiaye et al. 2020; Sharafi and Mohammadi Ghaleni 2021). The accuracy of this equation is due to its consideration of all climatic parameters, including solar radiation, air temperature, wind speed and relative humidity (Ndiaye et al. 2020). While the PM-FAO56 equation shows relatively stable results, the equations for empirical models based on temperature, solar radiation and mass transfer use fewer climatic parameters in the 


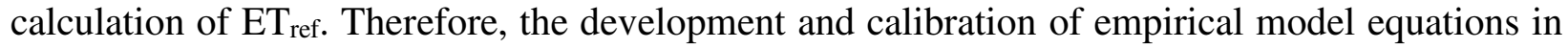
different climates can be more effective for agricultural and hydrological projects where only a few climatic variables are available (Heydari and Heydari, 2014; Gafurov et al. 2018).

Several researchers have evaluated the dependence of different empirical $\mathrm{ET}_{\text {ref }}$ equations on various meteorological parameters over different climates. Sharafi and Mohammadi Ghaleni (2021) evaluated different empirical equations for $\mathrm{ET}_{\text {ref }}$ in different climates of Iran. Their results found that the simplest regression model (MLR) based on minimum and maximum temperature data was more precise than the empirical equations. They also recommended the solar radiationbased Irmak equation as the best substitute for the PM-FAO 56 model, especially in dry and semidry climates. Celestin et al. (2020) compared the 32 empirical ET ref $_{\text {equations with the PM-FAO56 }}$ using data on temperature, solar radiation and mass transfer in northwest China. They found that the World Meteorological Organization (WMO) and the Mahringer equations for the mass transfer-based model provided the best results. Gao et al. (2017) also assessed different empirical $\mathrm{ET}_{\text {ref }}$ equations in various climates and observed that the Priestley-Taylor and Hargreaves equations worked best in dry and semidry climates, while the Makkink equation worked best in the humid climate of China.

Water resources in semiarid regions are vulnerable to the impacts of climate change and human activities, and the accurate estimation of $\mathrm{ET}_{\text {ref }}$ is a primary tool in the management of water resources. Therefore, the goals of this study were to: (I) evaluate the best empirical equation for different climates, (II) find the best substitutes for the PM-FAO56 model in different climates and (III) calibrate each of the 32 empirical $\mathrm{ET}_{\text {ref }}$ equations for different climates of Iran.

\section{Materials and Methods}

\subsection{Time and location scales}

Iran is in the northern hemisphere between 25 and 40 degrees latitude. For this study, meteorological data recorded between 1990 and 2019 were collected from 41 synoptic stations in the country. These data were collected by the National Meteorological Organization of Iran and include the monthly mean of minimum, mean and maximum air temperature, relative humidity, wind speed measured at $2 \mathrm{~m}$ height and solar radiation. The data were complete, and no data needed to be reconstructed.

According to the $\mathrm{FAO}_{56}$ index, Iran is classified into four climatic regions: very dry, dry, semidry and humid (Fig. 1). Fig. 1 shows the location and climate for each station used in this study. Six stations were in very dry climate, 17 stations in dry climate, 14 stations in semidry climate and 4 stations in humid climate (Fig. 1). 


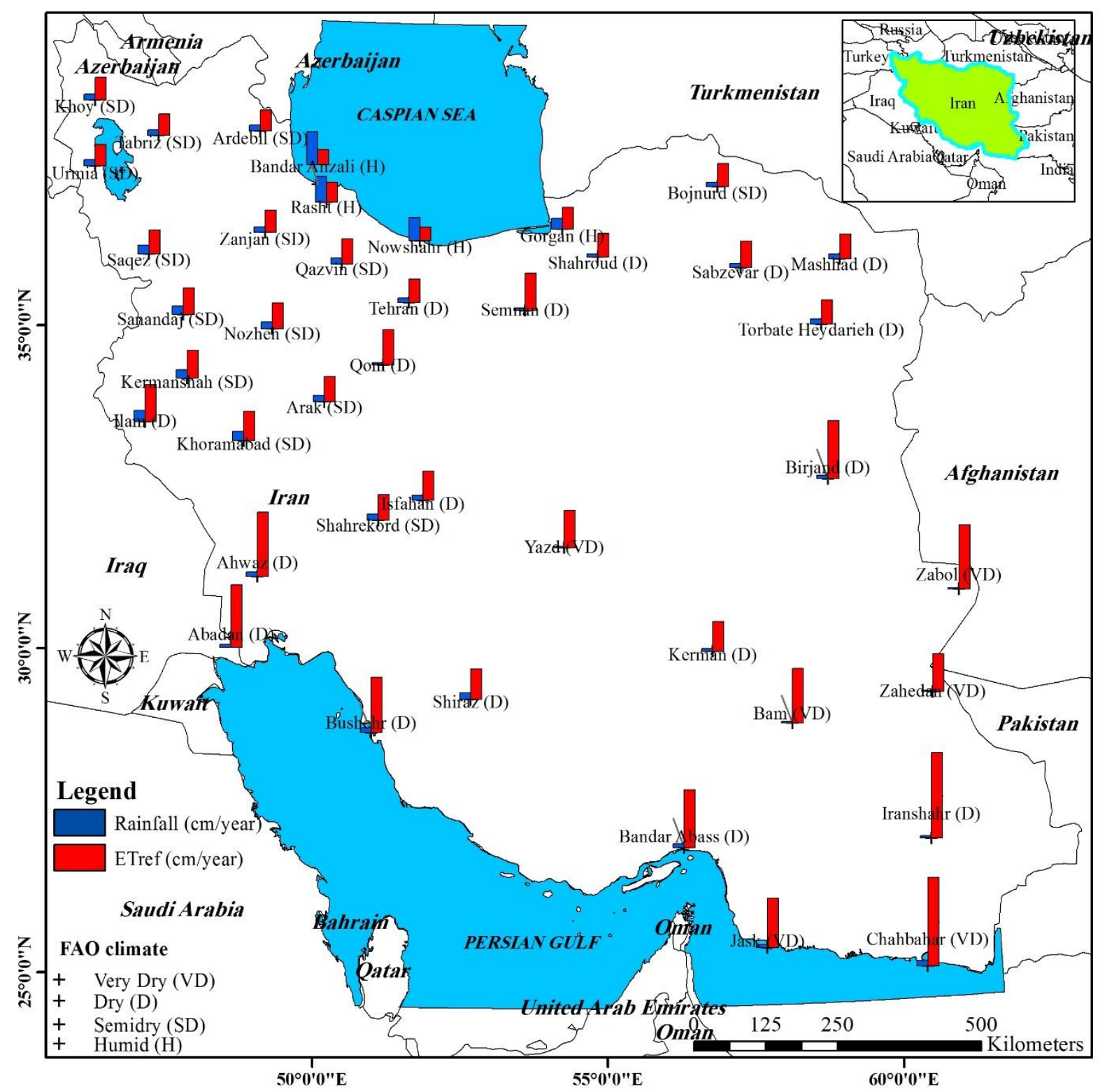

Fig. 1. Location and classification of studied stations based on the $\mathrm{FAO}_{56}$ method

\subsection{Empirical $E T_{\text {ref }}$ equations}

Based on the type and importance of input variables used in each empirical equation to calculate the $\mathrm{ET}_{\text {ref, }}$ the models were divided into 4 categories: combination-based (1 equation), temperaturebased ( 11 equations), solar radiation-based ( 11 equations) and mass transfer-based (10 equations). Table 1 lists the 33 empirical $\mathrm{ET}_{\text {ref }}$ equations used in this study and their respective references. 
Table 1. The $\mathbf{E T}_{\text {ref }}$ estimated based on empirical equations

\begin{tabular}{|c|c|c|c|}
\hline Code & Abs. & Empirical equations & References \\
\hline \multicolumn{4}{|c|}{ Combination-based } \\
\hline \multirow{2}{*}{1} & \multirow{2}{*}{$\mathrm{PM}^{\mathrm{FAO}} 56$} & \multirow{2}{*}{$E T_{r e f}=\frac{\Delta+\gamma\left(1+0.34 u_{2}\right)}{\Delta+x}$} & \multirow{2}{*}{ Allen et al. (2006) } \\
\hline & & & \\
\hline \multicolumn{4}{|c|}{ Temperature-based } \\
\hline 2 & HASA & $E T_{r e f}=\left[0.0023 \times R_{a}\left(T_{\text {mean }}+17.8\right)\left(T_{\max }-T_{\min }\right)^{0.5}\right] / \lambda$ & $\begin{array}{l}\text { Hargreaves and } \\
\text { Samani (1985) }\end{array}$ \\
\hline 3 & TRAJ & $E T_{r e f}=\left[0.0023 \times R_{a}\left(T_{\text {mean }}+17.8\right)\left(T_{\max }-T_{\min }\right)^{0.424}\right] / \lambda$ & Trajkovic (2007) \\
\hline 4 & TATA1 & $E T_{r e f}=\left[0.0031 \times R_{a}\left(T_{\text {mean }}+17.8\right)\left(T_{\max }-T_{\min }\right)^{0.5}\right] / \lambda$ & $\begin{array}{l}\text { Tabari and Talaee } \\
\text { (2011) }\end{array}$ \\
\hline 5 & TATA2 & $E T_{\text {ref }}=\left[0.0028 \times R_{a}\left(T_{\text {mean }}+17.8\right)\left(T_{\max }-T_{\min }\right)^{0.5}\right] / \lambda$ & $\begin{array}{l}\text { Tabari and Talaee } \\
\text { (2011) }\end{array}$ \\
\hline 6 & DRAL1 & $E T_{r e f}=\left[0.003 \times R_{a}\left(T_{\text {mean }}+20\right)\left(T_{\max }-T_{\min }\right)^{0.4}\right] / \lambda$ & $\begin{array}{l}\text { Droogers and Allen } \\
(2002)\end{array}$ \\
\hline 7 & DRAL2 & $E T_{\text {ref }}=\left[0.0025 \times R_{a}\left(T_{\text {mean }}+16.8\right)\left(T_{\max }-T_{\min }\right)^{0.5}\right] / \lambda$ & $\begin{array}{l}\text { Droogers and Allen } \\
(2002)\end{array}$ \\
\hline 8 & BERT & $E T_{r e f}=\left[0.00193 \times R_{a}\left(T_{\text {mean }}+17.8\right)\left(T_{\max }-T_{\min }\right)^{0.517}\right] / \lambda$ & Berti et al. (2014) \\
\hline 9 & DORJ & $E T_{r e f}=\left[0.002 \times R_{a}\left(T_{\text {mean }}+33.9\right)\left(T_{\max }-T_{\min }\right)^{0.296}\right] / \lambda$ & Dorji et al. (2016) \\
\hline 10 & BARO & $E T_{r e f}=0.109 \times\left(R_{a} / \lambda\right)+0.157 T_{\max }+0.158\left(T_{\max }-T_{\min }\right)-5.39$ & $\begin{array}{l}\text { Baier and Robertson } \\
\text { (1965) }\end{array}$ \\
\hline 11 & AHOO1 & $E T_{\text {ref }}=0.252 \times\left(R_{a} / \lambda\right)+0.221 T_{\text {mean }}(1-R H / 100)$ & $\begin{array}{l}\text { Ahooghalandari } \\
(2016)\end{array}$ \\
\hline 12 & AHOO2 & $E T_{r e f}=0.29 \times\left(R_{a} / \lambda\right)+0.15 T_{\max }(1-R H / 100)$ & $\begin{array}{l}\text { Ahooghalandari } \\
\text { (2016) }\end{array}$ \\
\hline \multicolumn{4}{|c|}{ Solar radiation-based } \\
\hline 13 & MAKK & $E T_{r e f}=0.7 \times\left(R_{a} / \lambda\right) \times[\Delta / \Delta+\gamma]-0.12$ & Makkink (1957) \\
\hline 14 & PRTA & $E T_{r e f}=1.26 \times\left(R_{n}-G\right)[\Delta / \Delta+\gamma] / \lambda$ & $\begin{array}{l}\text { Priestley and Tayler } \\
(1972)\end{array}$ \\
\hline 15 & JEHA & $E T_{r e f}=\left(0.025 T_{\text {mean }}+0.08\right) / \lambda$ & $\begin{array}{l}\text { Jensen and Haise } \\
\text { (1963) }\end{array}$ \\
\hline 16 & HARG & $E T_{\text {ref }}=\left[0.0135\left(T_{\text {mean }}+17.8\right) R_{s}\right] / \lambda$ & Hargreaves (1975) \\
\hline 17 & ABTE1 & $E T_{r e f}=0.25 T_{\max } R_{s} / \lambda$ & Abtew (1996) \\
\hline 18 & ABTE2 & $E T_{r e f}=\left(T_{\max } / 56\right) \times\left(R_{s} / \lambda\right)$ & Abtew (1996) \\
\hline 19 & IRMA1 & $E T_{r e f}=-0.611+0.149 R_{s}+0.079 T_{\text {mean }}$ & Irmak et al. (2003) \\
\hline 20 & IRMA2 & $E T_{r e f}=0.469+0.289 R_{n}+0.023 T_{\text {mean }}$ & Irmak et al. (2003) \\
\hline 21 & TATA3 & $E T_{r e f}=-0.642+0.174 R_{s}+0.0353 T_{\text {mean }}$ & $\begin{array}{l}\text { Tabari and Talaee } \\
\text { (2011) }\end{array}$ \\
\hline 22 & TATA4 & $E T_{r e f}=-0.478+0.156 R_{s}-0.0112 T_{\max }+0.0733 T_{\min }$ & $\begin{array}{l}\text { Tabari and Talaee } \\
\text { (2011) }\end{array}$ \\
\hline 23 & OUDI & $E T_{r e f}=\left(R_{s} / \lambda\right) \times\left[T_{\text {mean }}+5\right] / 100$ & Oudin (2004) \\
\hline \multicolumn{4}{|c|}{ Mass transfer-based } \\
\hline 24 & DALT & $E T_{r e f}=\left(3.648+0.7223 u_{2}\right)\left(e_{s}-e_{a}\right)$ & Dalton (1802) \\
\hline 25 & MEYE & $E T_{r e f}=\left(3.75+0.503 u_{2}\right)\left(e_{s}-e_{a}\right)$ & Meyer (1926) \\
\hline 26 & ROHW & $E T_{r e f}=\left(3.3+0.891 u_{2}\right)\left(e_{s}-e_{a}\right)$ & Rohwer (1931) \\
\hline 27 & ALBR & $E T_{r e f}=\left(1.005+2.97 u_{2}\right)\left(e_{s}-e_{a}\right)$ & Albrecht (1950) \\
\hline
\end{tabular}




$\begin{array}{cccl}28 & \text { WMO } & E T_{r e f}=\left(1.298+0.934 u_{2}\right)\left(e_{s}-e_{a}\right) & \text { WMO (1966) } \\ 29 & \text { TRAB } & E T_{r e f}=0.3075 \times u_{2}^{0.5}\left(e_{s}-e_{a}\right) & \text { Trabert (1896) } \\ 30 & \text { BRWE } & E T_{r e f}=0.543 \times u_{2}^{0.456}\left(e_{s}-e_{a}\right) & \text { Brockamp and } \\ 31 & \text { MAHR } & E T_{r e f}=0.286 \times u_{2}^{0.5}\left(e_{s}-e_{a}\right) & \text { Wenner (1963) } \\ 32 & \text { PENM } & E T_{r e f}=\left(2.625+0.000479 u_{2}\right)\left(e_{s}-e_{a}\right) & \text { Mahringer (1970) } \\ 33 & \text { ROMA } & E T_{r e f}=0.00006(100-R H)\left(25+T_{\text {mean }}\right)^{2} & \text { Penman (1948) }\end{array}$

$\mathrm{ET}_{\text {ref; }}$; reference evapotranspiration $\left(\mathrm{mm} \mathrm{day}^{-1}\right), \Delta$; the slope of saturation vapor pressure curve $\left(\mathrm{mb}^{\circ} \mathrm{C}^{-1}\right)$, Rn; net solar radiation $\left(\mathrm{MJ} \mathrm{m}^{-2}\right.$ day $\left.^{-1}\right)$; $\mathrm{G}$; soil heat flux density $\left(\mathrm{mm}\right.$ day $\left.{ }^{-1}\right), \gamma$; psychometric constant $\left(\mathrm{kPa}^{\circ} \mathrm{C}^{-1}\right), \mathrm{T}_{\text {mean, max and min }}$, mean, maximum and minimum daily temperature $\left({ }^{\circ} \mathrm{C}\right)$, respectively, $\mathrm{u}_{2}$ : wind speed measured at $2 \mathrm{~m}$ height $\left(\mathrm{m} \mathrm{s}^{-1}\right), \mathrm{R}_{\mathrm{a}}$; extraterrestrial radiation $\left(\mathrm{mm} \mathrm{day}^{-1}\right), \kappa$; latent heat of vaporization $\left.(\mathrm{MJ} \mathrm{kg})^{-1}\right), \mathrm{RH}$; mean relative humidity $(\%), \mathrm{R}_{\mathrm{s}}$; solar radiation $\left(\mathrm{MJ} \mathrm{m}^{-2}\right.$ day $\left.^{-1}\right)$, $\mathrm{e}_{\mathrm{s}}$; saturation vapor pressure $(\mathrm{k} \mathrm{Pa}), \mathrm{e}_{\mathrm{a}}$; actual vapor pressure $(\mathrm{k} \mathrm{Pa})$ and $\left(\mathrm{e}_{\mathrm{s}}-\mathrm{e}_{\mathrm{a}}\right)$; saturation vapor pressure deficit $(\mathrm{k} \mathrm{Pa})$.

To calculate the PM-FAO 56 , measurements of the amount of total solar radiation at the Earth's surface $\left(\mathrm{R}_{\mathrm{s}}, \mathrm{MJ} \mathrm{m}^{-2} \mathrm{~d}^{-1}\right)$, maximum and minimum temperature, wind speed $\left(\mathrm{m} \mathrm{s}^{-1}\right)$ and lack of vapor pressure $\left(\mathrm{VPD}, \mathrm{kPa}\right.$ ) are required. Due to lack of access to $\mathrm{R}_{\mathrm{s}}$ and VPD, the FAO method was used (Gholipoor 2008). Daily values of $R_{s}$ were obtained from Hargreaves and Samani's equation (Mehdizadeh et al. 2017) and the modified Allen et al. (2006) equation. Solar radiation reaching the land surface $\left(\mathrm{R}_{\mathrm{n}}, \mathrm{MJ} \mathrm{m}^{-2} \mathrm{~d}^{-1}\right)$ was first measured above the Earth's atmosphere for each day of the year based on latitude and longitude and the solar constant (Allen et al. 2006). Then $R_{s}$ was calculated using Eq. 34:

$$
34 R s=K_{R s} \times\left(1+2.7 \times 10^{-5} \times A l t\right) \times\left(T_{\max }-T_{\min }\right)^{0.5} \times R_{n}
$$

where Alt is altitude $(\mathrm{m})$ and $\mathrm{K}_{\mathrm{Rs}}$ is the empirical constant, considered equal to 0.16 (Gholipoor, 2008). The $e_{s}$ calculation is obtained from the difference between the daily saturated water vapor pressure $\left(e_{\max }\right)$ and the actual water vapor pressure $\left(e_{a}\right)$. Relative humidity at temperature was assumed to be at least 100 percent and the values for $e_{a}$ were obtained from Eq. (35):

$$
35 \quad e_{a}=0.6108 \times \exp \frac{\left(17.27 \times T_{\min }\right)}{\left(T_{\min }+237.3\right)}
$$

In very dry and dry climates, the relative humidity at the $\mathrm{T}_{\min }$ may never reach 100 percent. Therefore, it was assumed that in these regions, $\mathrm{e}_{\mathrm{a}}$ values would occur at $\mathrm{T}_{\min }>10^{\circ} \mathrm{C}$ and it was observed that in this case it had a minor effect on $\mathrm{ET}_{\text {ref }}(1-2 \%)$. As a result, the $\mathrm{ET}_{\text {ref }}$ was calculated assuming that the dew point was equal to the $\mathrm{T}_{\min }$. Then the $\mathrm{T}_{\max }$ saturated vapor pressure during the day ( $\mathrm{e}_{\max }$ ) depending on the $\mathrm{T}_{\max }$ was obtained from Eq. (36).

$$
36 \quad e_{\max }=0.6108 \times \exp \frac{\left(17.27 \times T_{\max }\right)}{\left(T_{\max }+237.3\right)}
$$

where $e_{s}$ is obtained from the mean $e_{a}$ and $e_{\max }$. Finally, $e_{s}$ is calculated as the average between $e_{a}$ and $e_{\max }$ in a part of the day when the air temperature is not at its maximum. However, other researchers have found that $\left(\mathrm{e}_{\max }-\mathrm{e}_{\mathrm{a}}\right) \times 0.75$ is a more accurate estimate of $\mathrm{e}_{\mathrm{a}}$ (Tanner and Sinclair, 1983; Allen et al. 1998). Therefore, this method is used in this current study. Calculations were performed using SAS software (Statistical Analysis System, Version 9.1, SAS Inst., Cary, NC).

The average annual rainfall over the last thirty years in Iran was reported to be $334 \mathrm{~mm}$. The highest annual rainfall occurred at Bandar Anzali station $(1791.78 \mathrm{~mm})$ and the lowest annual rainfall occurred at Bam station $(61.61 \mathrm{~mm})$. The average annual rainfall in the very dry climate was $92.89 \mathrm{~mm}$, which was $140.74,266.41$ and $1150.05 \mathrm{~mm}$ less than in dry, semidry and humid climates, respectively (Fig. 2a). The annual average relative humidity in Iran was reported to be 
55.34 percent with the highest relative humidity at Bandar Anzali station (84.71\%) and the lowest relative humidity at Bam station $(28.08 \%)$. The relative humidity in the very dry climate was 44.64 percent, which was 1.02, 7.9 and 35.93 percent less than in the dry, semidry and humid climates, respectively (Fig. 2b).

The 30-year average air temperature in Iran was reported to be $17.54{ }^{\circ} \mathrm{C}$. The hottest and coldest stations in this study were the Bandar Abbas and Ardabil stations ( 26.63 and $9.14{ }^{\circ} \mathrm{C}$, respectively). The average air temperature in the very dry climate was $20.44{ }^{\circ} \mathrm{C}$, which was $3.4,10.15$ and 6.04 ${ }^{\circ} \mathrm{C}$ warmer than in the dry, semidry and humid climates, respectively (Fig. 2c). The average solar radiation received in Iran is reported to be $7.26 \mathrm{MJ} \mathrm{m}^{-2} \mathrm{day}^{-1}$. The highest and lowest received solar radiation was observed in Bam and Rasht stations (9.06 and 4.17 $\mathrm{MJ} \mathrm{m}^{-2}$ day $^{-1}$, respectively).The average solar radiation received in the very dry climate was $8.55 \mathrm{MJ} \mathrm{m}^{-2}$ day ${ }^{-1}$, which increased by $0.36,1.06$ and $3.74 \mathrm{MJ} \mathrm{m}^{-2}$ day $^{-1}$ in dry, semidry and humid climates (Fig. $2 \mathrm{~d}$ ). The average wind speed in the country during the last thirty years was reported to be $4.35 \mathrm{~m} \mathrm{~s}^{-1}$, which has increased by about $0.52 \mathrm{~m} \mathrm{~s}^{-1}$ compared to the same period. The highest and lowest wind speeds were recorded in Zabol and Gorgan stations, respectively (10.62 and $\left.1.45 \mathrm{~m} \mathrm{~s}^{-1}\right)$. The mean wind speed in a very dry climate was $6.54 \mathrm{~m} \mathrm{~s}^{-1}$, which increased by $2.15,2.63$ and $3.97 \mathrm{~m} \mathrm{~s}^{-1}$ in dry, semidry and humid climates (Fig. 2e). 


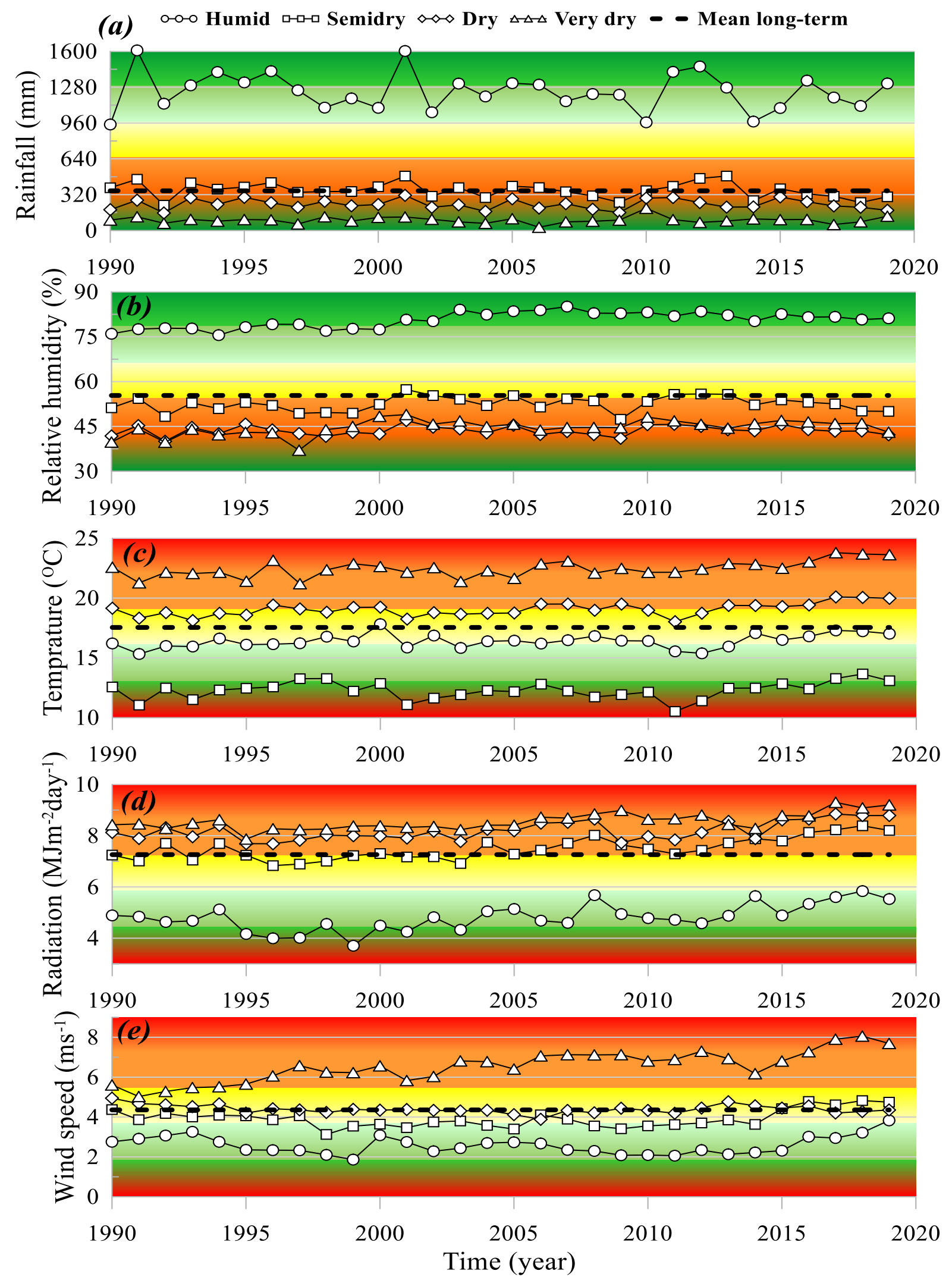

Fig. 2. The long period values of a) rainfall, b) relative humidity, c) temperature, d) solar radiation and e) wind speed of Iran's climate (1990-2019) 
(41) Index of agreement (D)

Scatter Index (SI)

Root mean square error (RMSE)

Average percentage

error (APE)

Mean bias error (MBE)
Table 2. The characteristics of evaluation performance criteria used in the study

$$
\text { Equation }
$$

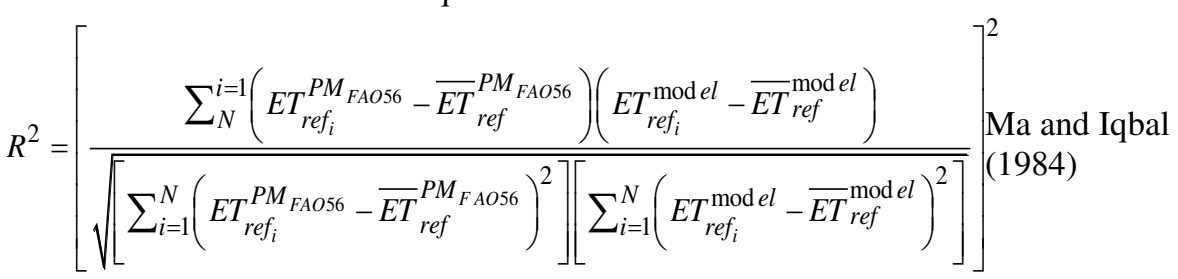

$$
\begin{aligned}
& R M S E=\sqrt{\frac{1}{N} \sum_{i=1}^{N}\left(E T_{r e f}^{\text {model }}-E T_{r e f}^{P M_{F 56}}\right)^{2}} \quad \text { Ma and Iqbal } \\
& A P E=\frac{\sum_{i=1}^{N}\left|E T_{\text {ref }_{i}}^{P M_{\text {FAO56 }}}-E T_{\text {ref }}^{\text {mod } e l}\right|}{\sum_{i=1}^{N} E T_{r e f_{i}}^{P M_{\text {FAO56 }}}} \times 100 \%
\end{aligned}
$$

$$
\begin{array}{cl}
M B E=\frac{1}{N} \sum_{N}^{i=1}\left(E T_{\text {ref }_{i}}^{\text {model }}-E T_{\text {ref }_{i}}^{P M_{F A O 56}}\right) & \begin{array}{l}
\text { Ferreira and } \\
\text { da Cunha } \\
(2020)
\end{array} \\
D=1-\frac{\sum_{N}^{i=1}\left(E T_{r e f_{i}}^{\text {model }}-E T_{r e f_{i}}^{P M_{F A O 56}}\right)^{2}}{\sum_{N}^{i=1}\left(\left|E T_{r e f_{i}}^{\text {model }}-\overline{E T}{ }_{r e f}^{P M_{F A O 56}}\right|+\left|E T_{r e f_{i}}^{\text {model }}-\overline{E T}{ }_{r e f}^{P M_{F A O 56}}\right|\right)^{2}} & \begin{array}{l}
\text { Seifi and } \\
\text { Riahi-Madvar }
\end{array}
\end{array}
$$

Ferreira and da Cunha (2020) $S I=\frac{R M S E}{\overline{E T}_{r e f}^{P M_{F A O 56}}}$

Li et al. (2013)

In Eqs. (37) to (42), $E T_{r e f_{i}}^{P M_{F A O 56}}$ and $E T_{r_{e} f_{i}}^{\text {model }}$ are the $E T_{\text {ref }}$ based on PM-FAO56, and modeled $\mathrm{ET}_{\text {ref }}, \overline{E T}_{r e f}^{P M_{F A O 56}}$ and $\overline{E T}_{\text {ref }}^{\text {mod } e l}$ are the mean values of $\mathrm{ET}_{\text {ref }}$ based on PM-FAO56 and modeled ET $\mathrm{T}_{\text {ref }}$ and $\mathrm{N}$ is the number of data sets. According to Li et al. (2013), the range of SI for the accuracy of the models is excellent $(\mathrm{SI}<0.1)$, good $(0.1<\mathrm{SI}<0.2)$, fair $(0.2<\mathrm{SI}<0.3)$ and poor $(\mathrm{SI}>0.3)$.

\subsection{Empirical Equation Calibration}

The basis of empirical equations used in estimating $\mathrm{ET}_{\text {ref }}$ is the regression relationship between the $\mathrm{ET}_{\text {ref }}$ equation as a dependent variable and meteorological parameters as independent variables. In the process of developing each of the empirical equations, one of two modifications may be made, either a change in meteorological parameters or a change in the coefficients of the equation. In this study, modification (optimization) of constant coefficients in empirical equations is the basis for increasing the accuracy of $\mathrm{ET}_{\text {ref }}$ estimation in different climates. The objective function of that change has been to minimize the RMSE error criterion by optimizing the constant coefficients of the equations as decision variables. For instance, in the HASA equation, the two 
coefficients $\mathrm{a}$ and $\mathrm{b}$ in Eq. (43) are optimized to minimize the amount of error between the estimated $\mathrm{ET}_{\text {ref }}$ and the PM-FAO 56 .

$$
E T_{\text {ref }}=\left[a \times R_{a}\left(T_{\text {mean }}+17.8\right)\left(T_{\max }-T_{\min }\right)^{b}\right] / \lambda
$$

The accuracy of empirical equations in estimating $\mathrm{ET}_{\text {ref }}$ before and after calibration was evaluated using error evaluation criteria separately for various empirical equations (temperaturebased, solar radiation-based and mass transfer-based) and for very dry, dry, semidry and humid climates.

\section{Results \\ 3.1. Accuracy evaluation of empirical equations}

To assess the 32 empirical equations for temperature-based, solar radiation-based and mass transfer-based models in different climates, meteorological datasets from 1990 to 2019 were evaluated. Table 3 shows the values of $\mathrm{R}^{2}$ and RMSE for original and calibrated empirical equations based on temperature, solar radiation and mass transfer methods in different climates. According to the results of the best values of $\mathrm{R}^{2}$ and RMSE in the temperature-based BARO equation for very dry (0.71 and 65.05), dry (0.63 and 74.69), semidry (0.46 and 60.25) and humid (0.59 and 73.35) climates observed in original BARO equation. These values after calibration were 0.82 and 32.79 in very dry climate, 0.73 and 42.12 in dry climate, 0.65 and 30.34 in semidry climate and 0.71 and 35.29 in humid climate. The DRAL1 equation in dry climate (0.73 and 36.4), and BERT equation in semidry ( 0.66 and 31.16$)$ and humid climates $(0.7$ and 30.58$)$ had acceptable results (Table 3).

For solar radiation-based methods, the maximum $\mathrm{R}^{2}$ in very dry, dry and humid climates derived by the original HARG equation was $0.6,0.47$ and 0.45 , respectively, but the best RMSE in very dry climate obtained by the original IRMA1 equation was 67.51, and in dry and humid climates as obtained by the original JEHA equation was 65.92 and 66.77, respectively. The result for calibrated equations showed that in very dry $\left(R^{2}=0.84\right.$ and $\left.R M S E=33.13\right)$, dry $\left(R^{2}=0.74\right.$ and RMSE $=34.9)$ and semidry $\left(\mathrm{R}^{2}=0.63\right.$ and $\left.\mathrm{RMSE}=34.36\right)$ climates, the OUDI, ABTE2 and TATA3 equations yielded reliable estimates. In the humid climate calibrated PRTA and MAKK equations showed the maximum $\mathrm{R}^{2}=0.71$ and the minimum RMSE $=33.71$ (Table 3).

The results from mass transfer-based methods showed that the values of $\mathrm{R}^{2}$ for the original PEMN equation in very dry, dry, semidry and humid climates were acceptable $(0.74,0.7,0.53$ and 0.64 , respectively).The values of RMSE for the original PENM equation were reported as 54.17 for very dry, 53.13 for dry and 46.46 for semidry climates, but the best value of RMSE for humid climates, 49.2, was obtained by the original ROMA equation.

The results from mass transfer-based methods showed that the values of $\mathrm{R}^{2}$ for the calibrated PEMN equation in very dry, dry, semidry and humid climates were acceptable $(0.85,0.79,0.71$ and 0.77 , respectively). The values of RMSE for the calibrated PEMN equation were 27.87 for very dry, 31.83 for dry and 29.38 for semidry climates, but the best value of RMSE for humid climates, 30.14, was obtained by the calibrated ROMA equation (Table 3 ). 
Table 3. The original and calibrated values of $\mathbf{R}^{2}$ and $R M S E$ for empirical $\mathbf{E} T_{\text {ref }}$ equations in different climates of Iran

\begin{tabular}{|c|c|c|c|c|c|c|c|c|c|c|c|c|c|c|c|c|c|}
\hline & & \multicolumn{4}{|c|}{ Very dry } & \multicolumn{4}{|c|}{ Dry } & \multicolumn{4}{|c|}{ Semidry } & \multicolumn{4}{|c|}{ Humid } \\
\hline & & \multicolumn{2}{|c|}{$\mathrm{R}^{2}$} & \multicolumn{2}{|c|}{ RMSE } & \multicolumn{2}{|c|}{$\mathrm{R}^{2}$} & \multicolumn{2}{|c|}{ RMSE } & \multicolumn{2}{|c|}{$\mathrm{R}^{2}$} & \multicolumn{2}{|c|}{ RMSE } & \multicolumn{2}{|c|}{$\mathrm{R}^{2}$} & \multicolumn{2}{|c|}{ RMSE } \\
\hline \multicolumn{2}{|c|}{ Equation } & Ori. & Cal. & Ori. & Cal. & Ori. & Cal. & Ori. & Cal. & Ori. & Cal. & Ori. & Cal. & Ori. & Cal. & Ori. & Cal. \\
\hline \multirow{11}{*}{ 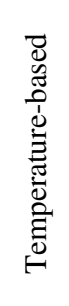 } & HASA & 0.54 & 0.77 & 83.38 & 43.99 & 0.44 & 0.70 & 82.41 & 37.67 & 0.32 & 0.59 & 79.99 & 34.41 & 0.42 & 0.67 & 70.15 & 37.23 \\
\hline & TRAJ & 0.54 & 0.80 & 80.48 & 39.18 & 0.44 & 0.69 & 77.59 & 40.29 & 0.28 & 0.60 & 77.87 & 35.63 & 0.40 & 0.68 & 80.81 & 38.80 \\
\hline & TATA1 & 0.49 & 0.78 & 78.73 & 40.66 & 0.34 & 0.68 & 76.75 & 39.46 & 0.20 & 0.59 & 62.12 & 32.56 & 0.32 & 0.68 & 73.03 & 34.94 \\
\hline & TATA2 & 0.53 & 0.76 & 73.20 & 39.97 & 0.38 & 0.68 & 83.42 & 40.71 & 0.36 & 0.61 & 74.34 & 34.37 & 0.39 & 0.68 & 85.12 & 34.05 \\
\hline & DRAL1 & 0.50 & 0.75 & 70.68 & 38.78 & 0.41 & 0.73 & 82.01 & 36.40 & 0.36 & 0.62 & 70.43 & 32.65 & 0.40 & 0.70 & 85.27 & 37.61 \\
\hline & DRAL2 & 0.48 & 0.79 & 84.88 & 43.97 & 0.36 & 0.67 & 72.66 & 41.21 & 0.23 & 0.55 & 69.24 & 36.91 & 0.32 & 0.66 & 78.29 & 35.49 \\
\hline & BERT & 0.52 & 0.79 & 83.42 & 36.88 & 0.42 & 0.70 & 77.57 & 37.81 & 0.27 & 0.66 & 82.50 & 31.16 & 0.39 & 0.70 & 67.92 & 30.58 \\
\hline & DORJ & 0.53 & 0.78 & 90.22 & 41.95 & 0.40 & 0.69 & 82.48 & 39.61 & 0.26 & 0.62 & 74.14 & 33.37 & 0.38 & 0.69 & 70.24 & 32.08 \\
\hline & BARO & 0.71 & 0.82 & 65.05 & 32.79 & 0.63 & 0.73 & 74.69 & 42.12 & 0.46 & 0.65 & 60.25 & 30.34 & 0.59 & 0.71 & 73.35 & 35.29 \\
\hline & AHOO1 & 0.56 & 0.79 & 72.75 & 40.43 & 0.42 & 0.72 & 80.13 & 38.94 & 0.31 & 0.62 & 73.51 & 33.57 & 0.41 & 0.70 & 73.69 & 32.84 \\
\hline & $\mathrm{AHOO} 2$ & 0.54 & 0.76 & 65.58 & 38.36 & 0.39 & 0.71 & 81.70 & 38.74 & 0.28 & 0.59 & 76.76 & 39.36 & 0.39 & 0.68 & 67.84 & 36.71 \\
\hline \multirow{11}{*}{ 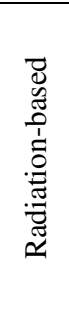 } & MAKK & 0.43 & 0.77 & 69.82 & 32.77 & 0.42 & 0.71 & 66.56 & 37.34 & 0.24 & 0.52 & 56.31 & 36.24 & 0.37 & 0.66 & 75.22 & 33.71 \\
\hline & PRTA & 0.49 & 0.83 & 73.92 & 37.98 & 0.41 & 0.72 & 74.28 & 38.43 & 0.38 & 0.63 & 65.67 & 35.22 & 0.42 & 0.71 & 83.72 & 35.38 \\
\hline & JEHA & 0.50 & 0.78 & 71.27 & 32.39 & 0.42 & 0.69 & 65.92 & 37.25 & 0.42 & 0.60 & 53.08 & 34.23 & 0.44 & 0.68 & 66.77 & 41.86 \\
\hline & HARG & 0.60 & 0.79 & 71.45 & 37.54 & 0.47 & 0.70 & 82.83 & 41.01 & 0.35 & 0.57 & 77.92 & 36.34 & 0.45 & 0.68 & 69.82 & 34.75 \\
\hline & ABTE1 & 0.54 & 0.82 & 80.25 & 33.30 & 0.43 & 0.69 & 71.60 & 38.40 & 0.43 & 0.58 & 77.11 & 38.25 & 0.44 & 0.67 & 85.44 & 37.09 \\
\hline & ABTE2 & 0.51 & 0.77 & 78.60 & 35.59 & 0.44 & 0.74 & 85.22 & 34.90 & 0.35 & 0.59 & 75.66 & 35.93 & 0.42 & 0.69 & 82.89 & 38.51 \\
\hline & IRMA1 & 0.53 & 0.77 & 88.50 & 38.48 & 0.44 & 0.74 & 77.14 & 37.32 & 0.34 & 0.60 & 79.41 & 37.52 & 0.43 & 0.70 & 71.64 & 35.71 \\
\hline & IRMA2 & 0.55 & 0.80 & 67.51 & 32.29 & 0.45 & 0.71 & 77.56 & 38.52 & 0.35 & 0.61 & 77.79 & 41.90 & 0.43 & 0.69 & 69.01 & 38.63 \\
\hline & TATA3 & 0.51 & 0.78 & 79.88 & 38.96 & 0.44 & 0.72 & 71.85 & 39.05 & 0.36 & 0.63 & 78.98 & 34.36 & 0.42 & 0.70 & 74.70 & 35.57 \\
\hline & TATA4 & 0.45 & 0.77 & 82.61 & 39.48 & 0.42 & 0.70 & 78.05 & 54.78 & 0.28 & 0.60 & 76.11 & 35.62 & 0.38 & 0.68 & 79.58 & 40.30 \\
\hline & OUDI & 0.51 & 0.84 & 70.61 & 33.13 & 0.45 & 0.72 & 73.87 & 61.40 & 0.36 & 0.59 & 70.91 & 38.62 & 0.42 & 0.70 & 86.26 & 33.80 \\
\hline \multirow{10}{*}{ 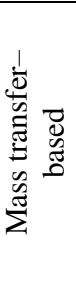 } & DALT & 0.56 & 0.82 & 66.53 & 31.11 & 0.59 & 0.71 & 76.56 & 53.83 & 0.36 & 0.65 & 66.21 & 36.12 & 0.51 & 0.71 & 75.23 & 34.40 \\
\hline & MEYE & 0.67 & 0.80 & 80.83 & 36.93 & 0.60 & 0.71 & 72.02 & 56.87 & 0.44 & 0.64 & 61.90 & 33.51 & 0.55 & 0.70 & 70.29 & 35.10 \\
\hline & ROHW & 0.68 & 0.76 & 72.71 & 38.88 & 0.58 & 0.73 & 74.26 & 52.57 & 0.31 & 0.63 & 70.95 & 38.54 & 0.50 & 0.70 & 67.41 & 36.73 \\
\hline & ALBR & 0.63 & 0.79 & 64.30 & 39.43 & 0.48 & 0.72 & 71.79 & 65.94 & 0.30 & 0.56 & 65.62 & 47.00 & 0.44 & 0.68 & 72.52 & 31.83 \\
\hline & WMO & 0.67 & 0.81 & 68.91 & 34.10 & 0.58 & 0.74 & 72.37 & 53.26 & 0.27 & 0.63 & 70.84 & 36.75 & 0.48 & 0.71 & 69.69 & 38.68 \\
\hline & TRAB & 0.69 & 0.82 & 71.94 & 36.76 & 0.62 & 0.71 & 73.93 & 36.43 & 0.31 & 0.63 & 70.26 & 36.38 & 0.51 & 0.71 & 81.45 & 38.86 \\
\hline & BRWE & 0.56 & 0.86 & 87.93 & 33.20 & 0.49 & 0.73 & 80.31 & 35.17 & 0.33 & 0.64 & 78.86 & 38.63 & 0.44 & 0.72 & 77.47 & 35.62 \\
\hline & MAHR & 0.61 & 0.83 & 71.85 & 33.01 & 0.64 & 0.75 & 71.92 & 35.79 & 0.32 & 0.62 & 75.02 & 35.87 & 0.51 & 0.71 & 75.93 & 37.77 \\
\hline & PENM & 0.74 & 0.85 & 54.17 & 27.87 & 0.70 & 0.79 & 53.13 & 31.83 & 0.53 & 0.71 & 46.46 & 29.38 & 0.64 & 0.77 & 56.72 & 31.71 \\
\hline & ROMA & 0.50 & 0.76 & 59.22 & 30.93 & 0.45 & 0.73 & 69.14 & 36.09 & 0.42 & 0.61 & 49.03 & 30.99 & 0.46 & 0.70 & 49.20 & 30.14 \\
\hline
\end{tabular}

Radar charts in Fig. 3 compare the APE values of the $E T_{r e f}^{P M_{F A O 56}}$ and the estimated $E T_{\text {ref }}$ using the original and calibrated empirical equations for temperature-based, solar radiation-based and mass transfer-based methods from 1990 to 2019. Based on the results of APE plots, calibration greatly improved the performance of all empirical equations in all investigated climates compared with the original empirical equations. After calibration, APE values are closer to zero.

A reduction in values of APE for the calibrated empirical equations was found in very dry, dry, semidry and humid climates in temperature-based (1, 1.5, 2.2 and 3.2\%), solar radiation-based (1, $1.4,1.9$ and $3.1 \%)$ and mass transfer-based $(1,1.3,1.6$ and $2.8 \%)$ methods when compared to the original equations (Fig. 3). This indicates the great effect calibration has relative to other empirical equations on increasing the accuracy of temperature-based methods. This increase confirms the accuracy of calibrated empirical equations in estimating $\mathrm{ET}_{\text {ref }}$ in humid climate. At the same time, the accuracy of $\mathrm{ET}_{\text {ref }}$ estimation for all empirical equations decreased from very dry to humid climates, indicating that the process of $\mathrm{ET}_{\text {ref }}$ estimation in humid climate is more complex due to its greater dependence on multiple climatic parameters.
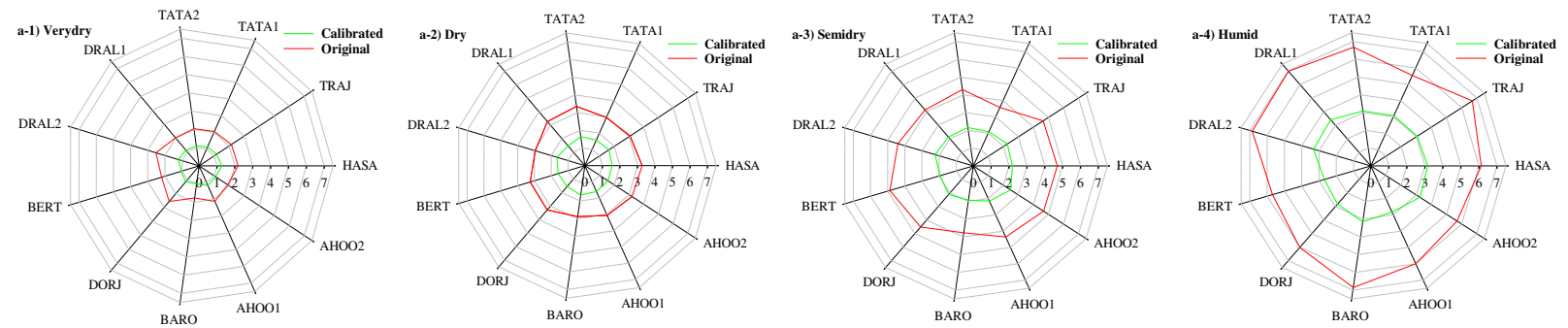

a) Temperature-based equations 

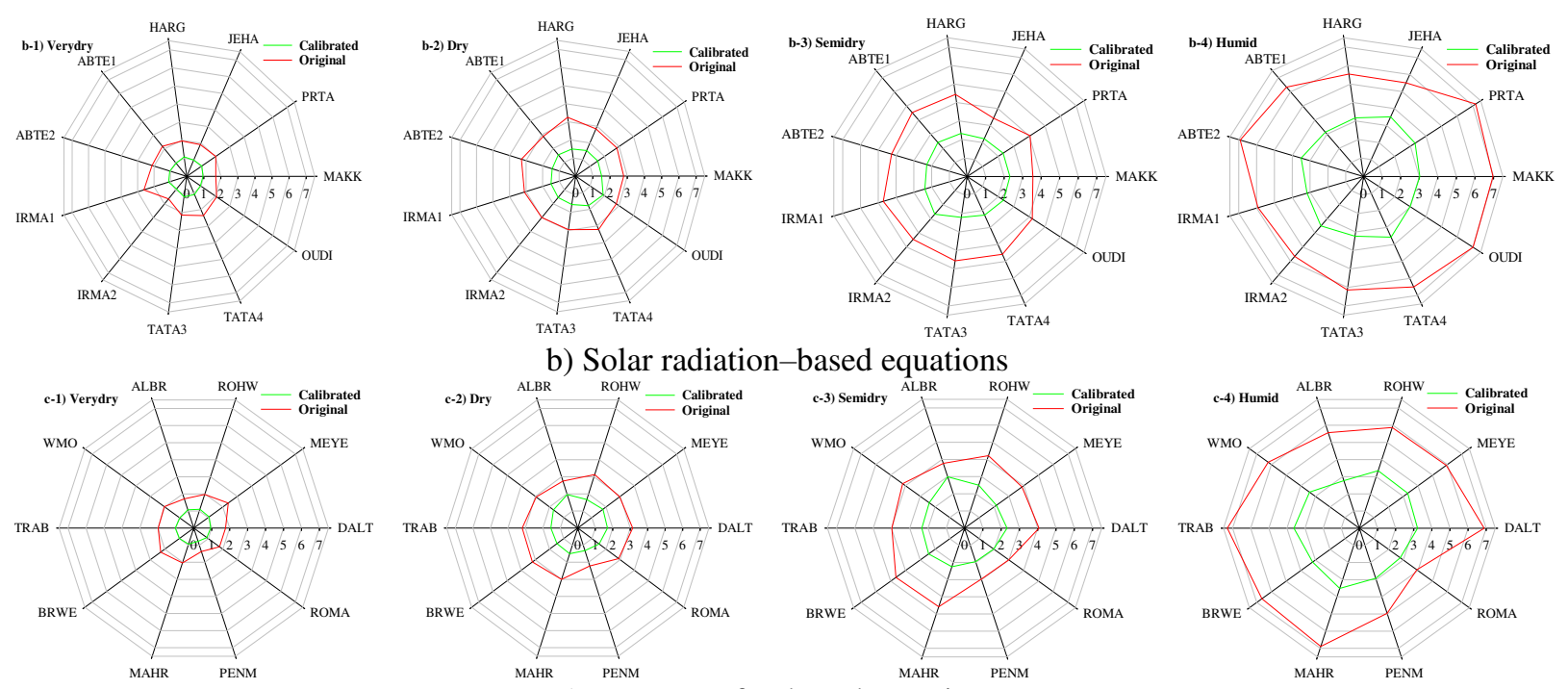

c) Mass transfer-based equations

Fig. 3. The APE performance of original and calibrated empirical equations in different climates

\subsection{Bias error evaluation of empirical equations}

Figure 4 shows a decrease in MBE for calibrated empirical equations compared to the original empirical equations. This error reduction is evident in all types of equations and in all climates. Figure 4-a shows the overestimation of most empirical temperature-based methods in very dry, semidry and humid climates. The highest accuracy of empirical equations for temperature-based and solar radiation-based methods for estimating $\mathrm{ET}_{\text {ref }}$ in dry climate (Figs. 4a-2 and b-2) is obtained when the MBE in this climate for all empirical equations is less than $20 \mathrm{~mm} \mathrm{year}^{-1}$. Figure 4-c shows the overestimation of $\mathrm{ET}_{\text {ref }}$ values for mass transfer-based empirical equations in humid climate and underestimation in very dry, dry and semidry climates. The highest accuracy of MBE is acquired by mass transfer-based methods in semidry climate.
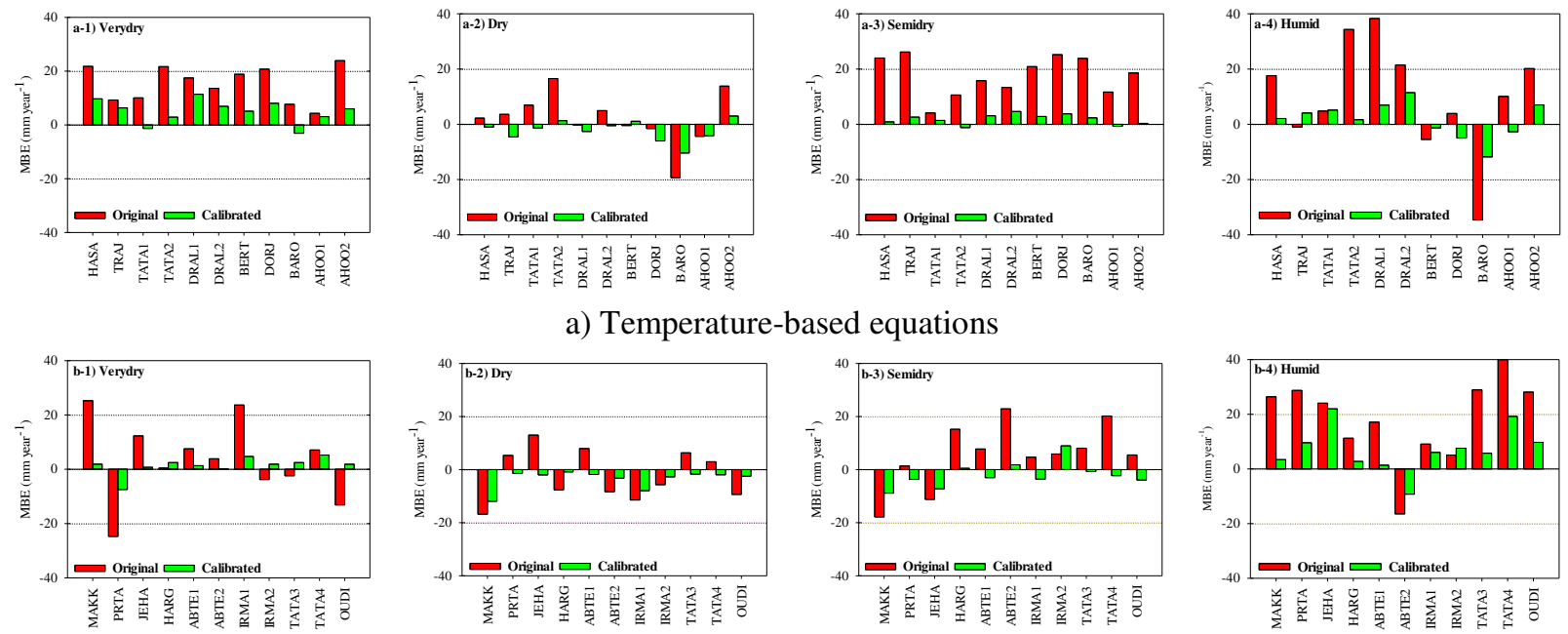

b) Solar radiation-based equations 

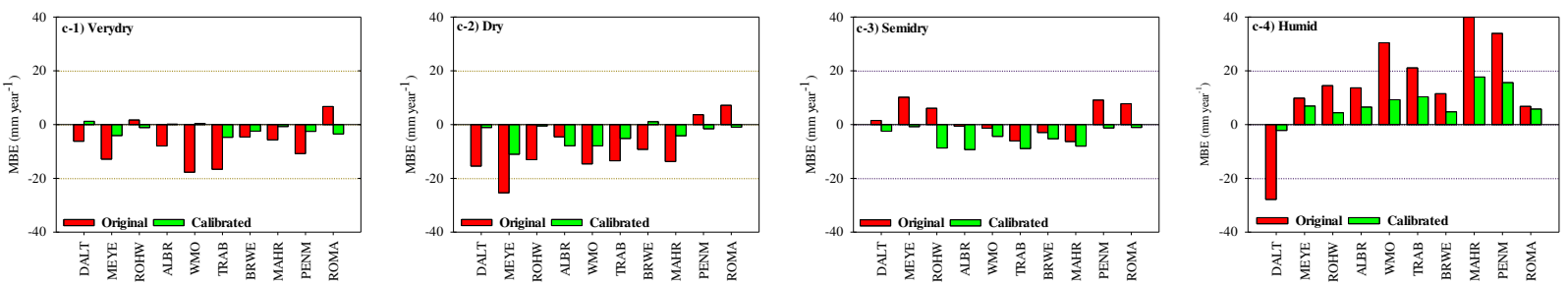

c) Mass transfer-based equations

Fig. 4. The MBE performance of original and calibrated empirical equations in different climates

\subsection{Correlation between PM-FAO 56 and empirical equations}

Based on the results presented in Table 3, the highest accuracy of empirical equations for temperature-based, solar radiation-based and mass transfer-based methods of estimating ET $_{\text {ref }}$ in different climates is determined by the BARO, JEHA and PENM equations, respectively. Figure 5 shows the values of $\mathrm{D}$ for the best equations of temperature-based, solar radiation-based and mass transfer-based methods in different climates. A better fit between the estimated $\mathrm{ET}_{\text {ref }}$ and $P M-F A O_{56}$ appears in the calibrated empirical equations when compared to the original empirical equations in all empirical equations and climates.

The best fit between the $P M-F A O_{56}$ and estimated $\mathrm{ET}_{\text {ref }}$ values is related to the calibrated PENM equation in humid climate and is equal to 0.94 (Fig. 5c-4). Generally, the best and worst fit between

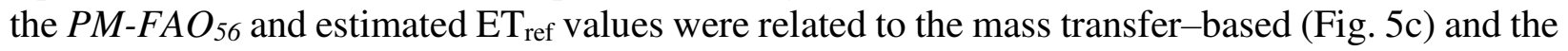
solar radiation-based methods (Fig. 5b).
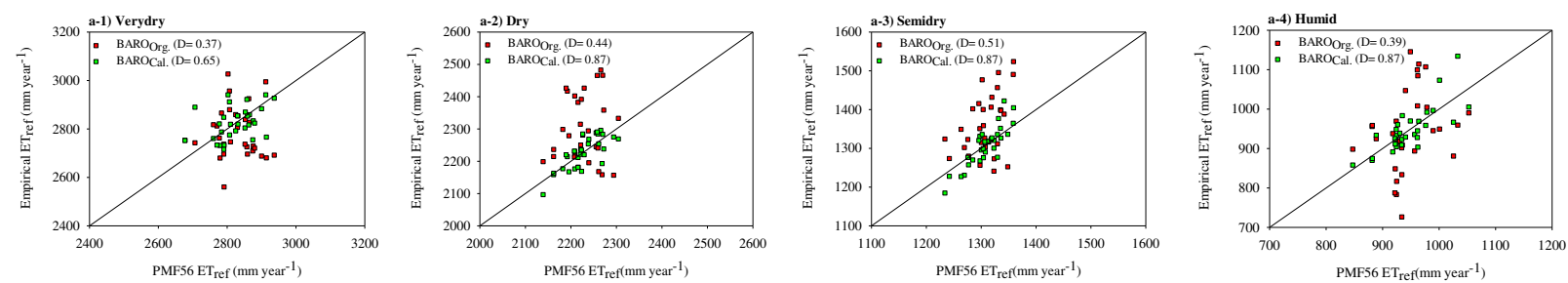

a) Temperature-based equations
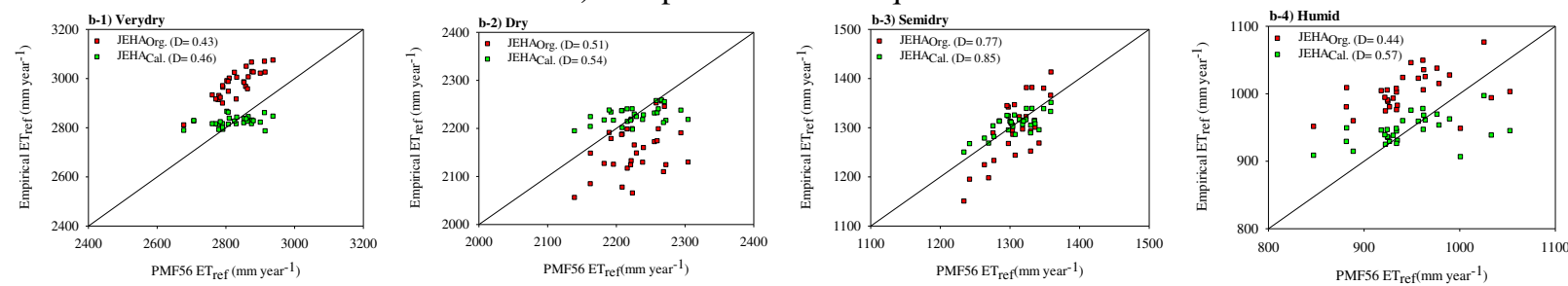

b) Solar radiation-based equations
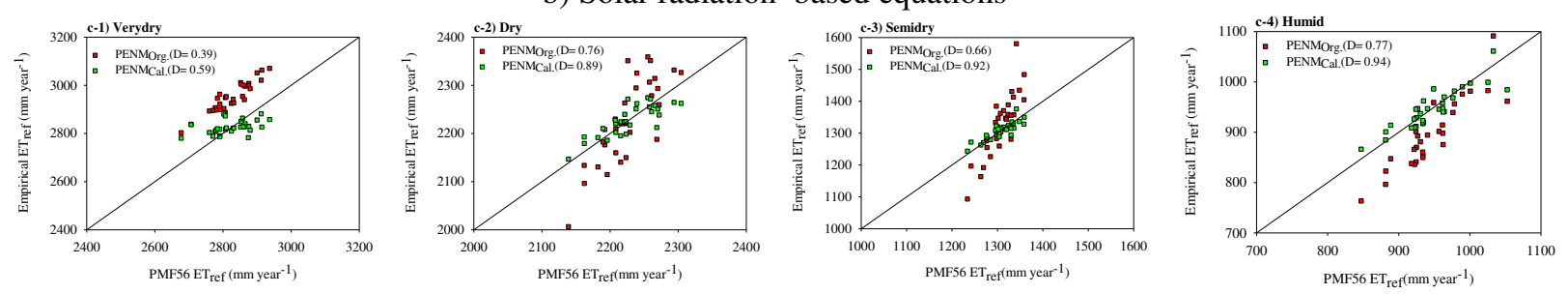

c) Mass transfer-based equations

Fig. 5. The D performance of original and calibrated empirical equations in different climates

Figure 6 shows $P_{M-F A O_{56}}$ and estimated $\mathrm{ET}_{\text {ref }}$ values for the best empirical equations in different climates during 1990 to 2019. The estimated $\mathrm{ET}_{\text {ref }}$ values using the empirical equations 
1 after calibration are very close to the calculated $\mathrm{ET}_{\text {ref }}$ values. This can especially be seen in the 2 calibrated PENM equation in semidry climate (Fig. 6c-3).
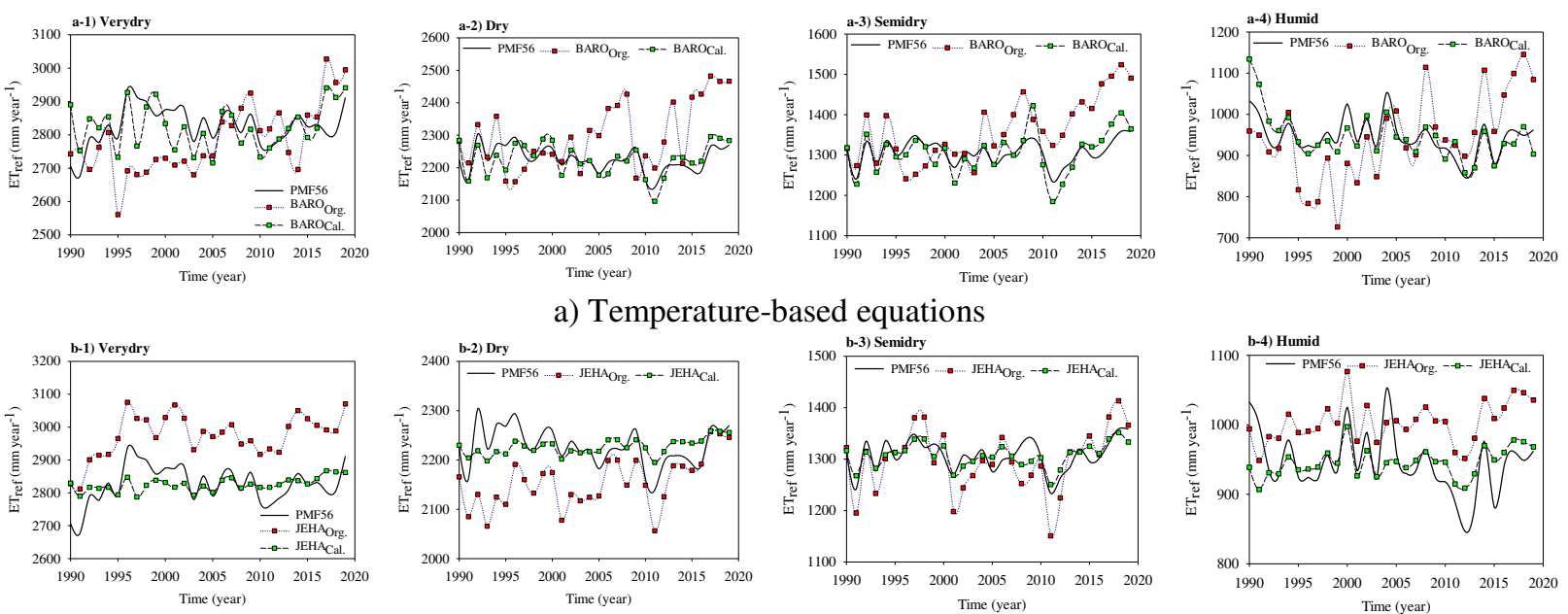

b) Solar radiation-based equations
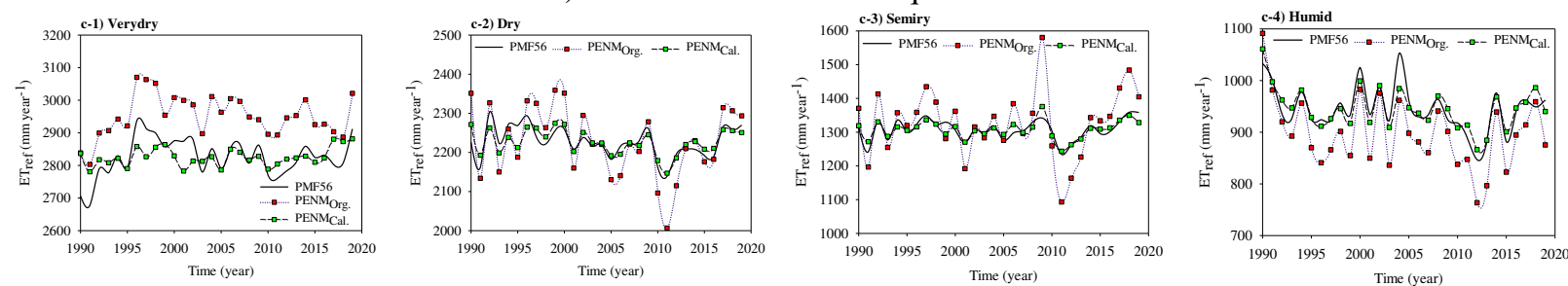

c) Mass transfer-based equations

Fig. 6. The estimated ET ref versus PM-FAO56 values in different climates

4

\subsection{SI map}

Figure 7 shows that calibration at stations with very dry climate, such as Zabol, Zahedan, Bam, Iranshahr and Chabahar stations, had a greater effect on the accuracy of $\mathrm{ET}_{\text {ref }}$ estimation based on the SI value in the excellent class (SI < 0.1). The highest amount of error in the SI index is related to stations with humid climates, such as Rasht and Nowshahr. This is due to the complexity of the $\mathrm{ET}_{\text {ref }}$ process in humid climate. 


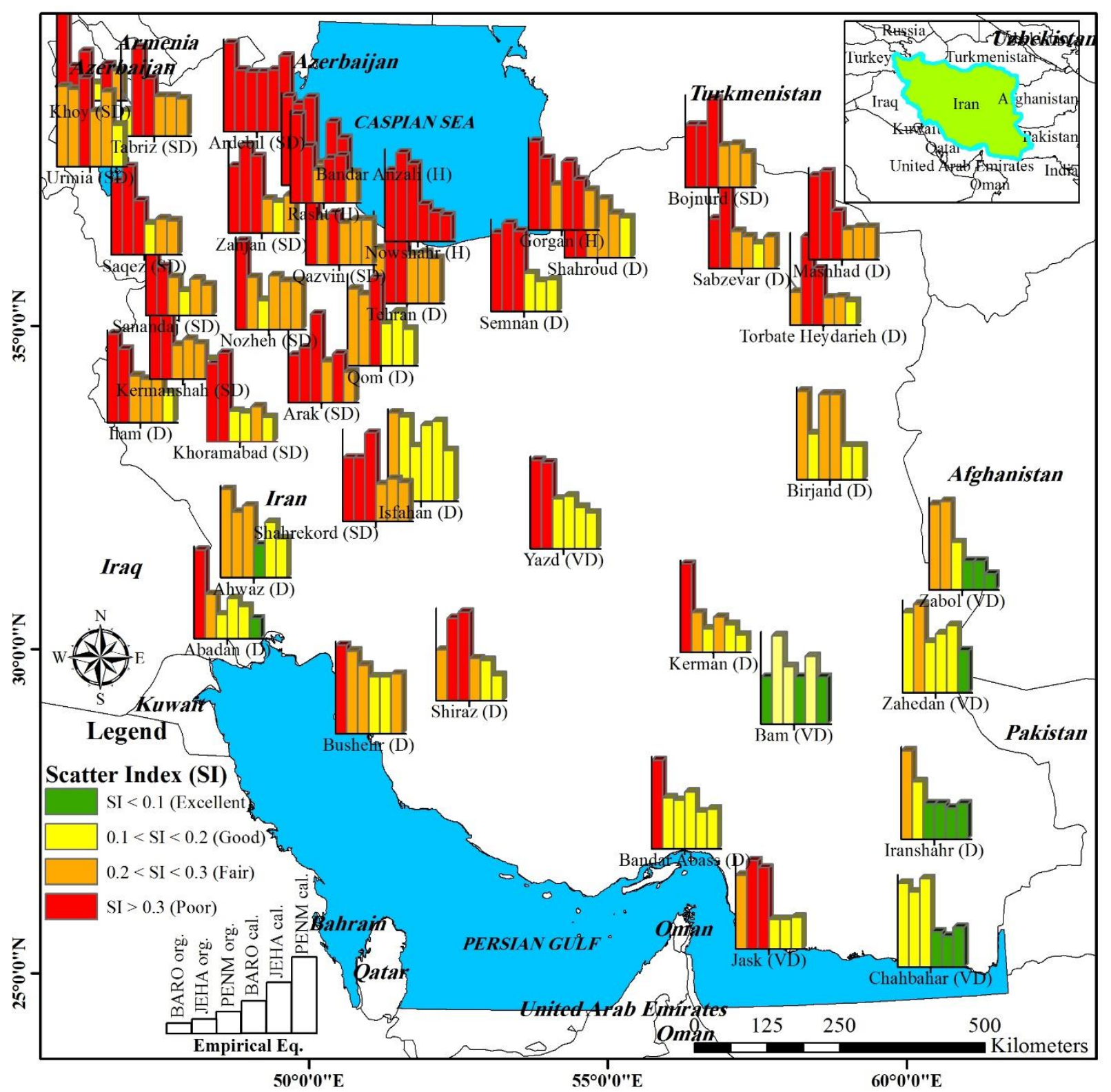

Fig. 7. SI map of the best empirical equations in different climates

\section{Conclusion}

In general, the results show that most of the empirical equations had good accuracy in estimating $\mathrm{ET}_{\text {ref }}$ in all studied climates. However, the accuracy of the $\mathrm{ET}_{\text {ref }}$ estimate before and after calibration depended on the classification of the equation in the type and number of input data and the type of climate under study. The results of various empirical equations for temperature-based, solar radiation-based and mass transfer-based $\mathrm{ET}_{\text {ref }}$ estimation in very dry, dry, semidry and humid climates showed that in each climate, specific empirical equations have the desired accuracy. In other words, each climatic region has its own superior empirical equation. Also, with the complexity of climatic variables, the accuracy of various empirical equations is associated with change.

Based on the lowest value of RMSE and the highest value of $\mathrm{R}^{2}$, the empirical equations BARO for temperature-based, JEHA for solar radiation-based and PENM for mass transfer-based 
methods showed the best results among the 32 empirical equations studied. The results of APE, MBE and D criteria show that the accuracy of the empirical equations after calibration increased significantly when compared to their original values. At the same time, the results of SI criterion and the effect of factors such as high relative humidity and the balance between air temperature and rainfall mean that the estimation of $\mathrm{ET}_{\mathrm{ref}}$ is more complex. Considering the dependence of the $\mathrm{ET}_{\text {ref }}$ process on fewer meteorological parameters, we can conclude that in very dry climates the empirical equations before and after calibration are more accurate.

Availability of data and material: All data used in this article have been prepared from the Meteorological Organization of Iran and after validation, have been used. In this study, meteorological information was used that lacked outdated data.

Code availability: The software used in this research will be available (by the corresponding author), upon reasonable request.

Ethics approval: We confirm that we have given due consideration to the protection of intellectual property associated with this work and that there are no impediments to publication, including the timing of publication, with respect to intellectual property.

Consent to participate: Conceptualization, Methodology, Technical Investigation, Writing (Original draft preparation), Supervision: S.S. and Software, Validation: M.M.G. All authors have read and agreed to the published version of the manuscript.

Consent for publication: We confirm that intellectual property associated with this work belong to the Journal of Theoretical and Applied Climatology.

Funding: This research was funded by Agricultural Experiment station of Arak University, Iran.

Acknowledgments: We thank Agricultural Experiment Station of Arak University and Ms. Sunny Skies.

Conflicts of Interest: The authors declare no conflict of interest.

\section{References}

Abtew W (1996) Evapotranspiration measurements and modeling for three wetland systems in South Florida 1 JAWRA Journal of the American Water Resources Association 32:465-473

Ahooghalandari M, Khiadani M, Jahromi ME (2016) Developing equations for estimating reference evapotranspiration in Australia Water Resources Management 30:3815-3828

Ahooghalandari M, Khiadani M, Jahromi ME (2017) Calibration of Valiantzas' reference evapotranspiration equations for the Pilbara region, Western Australia Theoretical and applied climatology 128:845-856

Albrecht F (1950) Die methoden zur bestimmung der verdunstung der natürlichen erdoberfläche Archiv für Meteorologie, Geophysik und Bioklimatologie, Serie B 2:1-38

Alijani B, Ghohroudi M, Arabi N (2008) Developing a climate model for Iran using GIS Theoretical and Applied Climatology 92:103-112

Allen RG et al. (2006) A recommendation on standardized surface resistance for hourly calculation of reference ETo by the FAO56 Penman-Monteith method Agricultural Water Management 81:1-22

Baier W, Robertson GW (1965) Estimation of latent evaporation from simple weather observations Canadian journal of plant science 45:276-284 
Bray RH, Kurtz L (1945) Determination of total, organic, and available forms of phosphorus in soils Soil science 59:39-46

Brockamp B, Wenner H (1963) Verdunstungsmessungen auf den Steiner see bei münster Dt Gewässerkundl Mitt 7:149-154

Celestin S, Qi F, Li R, Yu T, Cheng W (2020) Evaluation of 32 simple equations against the Penman-Monteith method to estimate the reference evapotranspiration in the Hexi Corridor, Northwest China Water 12:2772

Dorji U, Olesen JE, Seidenkrantz MS (2016) Water balance in the complex mountainous terrain of Bhutan and linkages to land use Journal of Hydrology: Regional Studies 7:55-68

Dalton J (1802) Experimental essays on the constitution of mixed gases Manchester Literary and Philosophical Society Memo 5:535-602

Droogers P, Allen RG (2002) Estimating reference evapotranspiration under inaccurate data conditions Irrigation and drainage systems 16:33-45

Ferreira LB, da Cunha FF (2020) New approach to estimate daily reference evapotranspiration based on hourly temperature and relative humidity using machine learning and deep learning Agricultural Water Management 234:106113

Ferreira LB, da Cunha FF, de Oliveira RA, Fernandes Filho EI (2019) Estimation of reference evapotranspiration in Brazil with limited meteorological data using ANN and SVM-A new approach Journal of hydrology 572:556-570

Gafurov Z, Eltazarov S, Akramov B, Yuldashev T, Djumaboev K, Anarbekov O (2018) Modifying hargreaves-samani equation for estimating reference evapotranspiration in dryland regions of Amudarya River Basin Agricultural Sciences 9:1354

Gangopadhyaya M (1966) Measurement and estimation of evaporation and evapotranspiration

Gao F, Feng G, Ouyang Y, Wang H, Fisher D, Adeli A, Jenkins J (2017) Evaluation of reference evapotranspiration methods in arid, semiarid, and humid regions JAWRA Journal of the American Water Resources Association 53:791-808

Güçlü YS, Subyani AM, Şen Z (2017) Regional fuzzy chain model for evapotranspiration estimation Journal of hydrology 544:233-241

Heydari MM, Heydari M (2014) Calibration of Hargreaves-Samani equation for estimating reference evapotranspiration in semiarid and arid regions Archives of Agronomy and Soil Science 60:695-713

Irmak S, Irmak A, Allen R, Jones J (2003) Solar and net radiation-based equations to estimate reference evapotranspiration in humid climates Journal of irrigation and drainage engineering 129:336-347

Jensen ME, Haise HR (1963) Estimating evapotranspiration from solar radiation Journal of the Irrigation and Drainage Division 89:15-41

Li M-F, Tang X-P, Wu W, Liu H-B (2013) General models for estimating daily global solar radiation for different solar radiation zones in mainland China Energy conversion and management 70:139-148

Mahringer W (1970) Verdunstungsstudien am neusiedler See Archiv für Meteorologie, Geophysik und Bioklimatologie, Serie B 18:1-20

Makkink GF (1957) Testing the Penman formula by means of lysimeters Journal of the Institution of Water Engineerrs 11:277-288

Mehdizadeh S, Saadatnejadgharahassanlou H, Behmanesh J (2017) Calibration of Hargreaves-Samani and PriestleyTaylor equations in estimating reference evapotranspiration in the Northwest of Iran Archives of Agronomy and Soil Science 63:942-955

Meyer A (1926) Über einige zusammenhänge zwischen klima und boden in Europa. ETH Zurich

Ndiaye PM, Bodian A, Diop L, Deme A, Dezetter A, Djaman K (2020) Evaluation and Calibration of Alternative Methods for Estimating Reference Evapotranspiration in the Senegal River Basin Hydrology 7:24

Penman HL (1963) Vegetation and hydrology Soil Science 96:357

Priestley CHB, TAYLOR RJ (1972) On the assessment of surface heat flux and evaporation using large-scale parameters Monthly weather review 100:81-92

Rohwer C (1931) Evaporation from free water surfaces. vol 271. US Department of Agriculture,

Romanenko V (1961) Computation of the autumn soil moisture using a universal relationship for a large area Proc of Ukrainian Hydrometeorological Research Institute 3:12-25

Saggi MK, Jain S (2019) Reference evapotranspiration estimation and modeling of the Punjab Northern India using deep learning Computers and Electronics in Agriculture 156:387-398

Seifi A, Riahi-Madvar H (2019) Improving one-dimensional pollution dispersion modeling in rivers using ANFIS and ANN-based GA optimized models Environmental Science and Pollution Research 26:867-885 
1

2
Sharafi S, Ghaleni MM (2021) Evaluation of multivariate linear regression for reference evapotranspiration modeling in different climates of Iran Theoretical and Applied Climatology 143:1409-1423

Shiri J, Marti P, Karimi S, Landeras G (2019) Data splitting strategies for improving data driven models for reference evapotranspiration estimation among similar stations Computers and Electronics in Agriculture 162:70-81

Tabari H, Talaee PH (2011) Local calibration of the Hargreaves and Priestley-Taylor equations for estimating reference evapotranspiration in arid and cold climates of Iran based on the Penman-Monteith model Journal of Hydrologic Engineering 16:837-845

Trabert W (1896) Neue beobachtungen über verdampfungsgeschwindigkeiten Meteorol Z 13:261-263

Trajkovic S (2007) Hargreaves versus Penman-Monteith under humid conditions Journal of Irrigation and Drainage Engineering 133:38-42

Vickers NJ (2017) Animal communication: when i'm calling you, will you answer too? Current biology 27:R713R715 


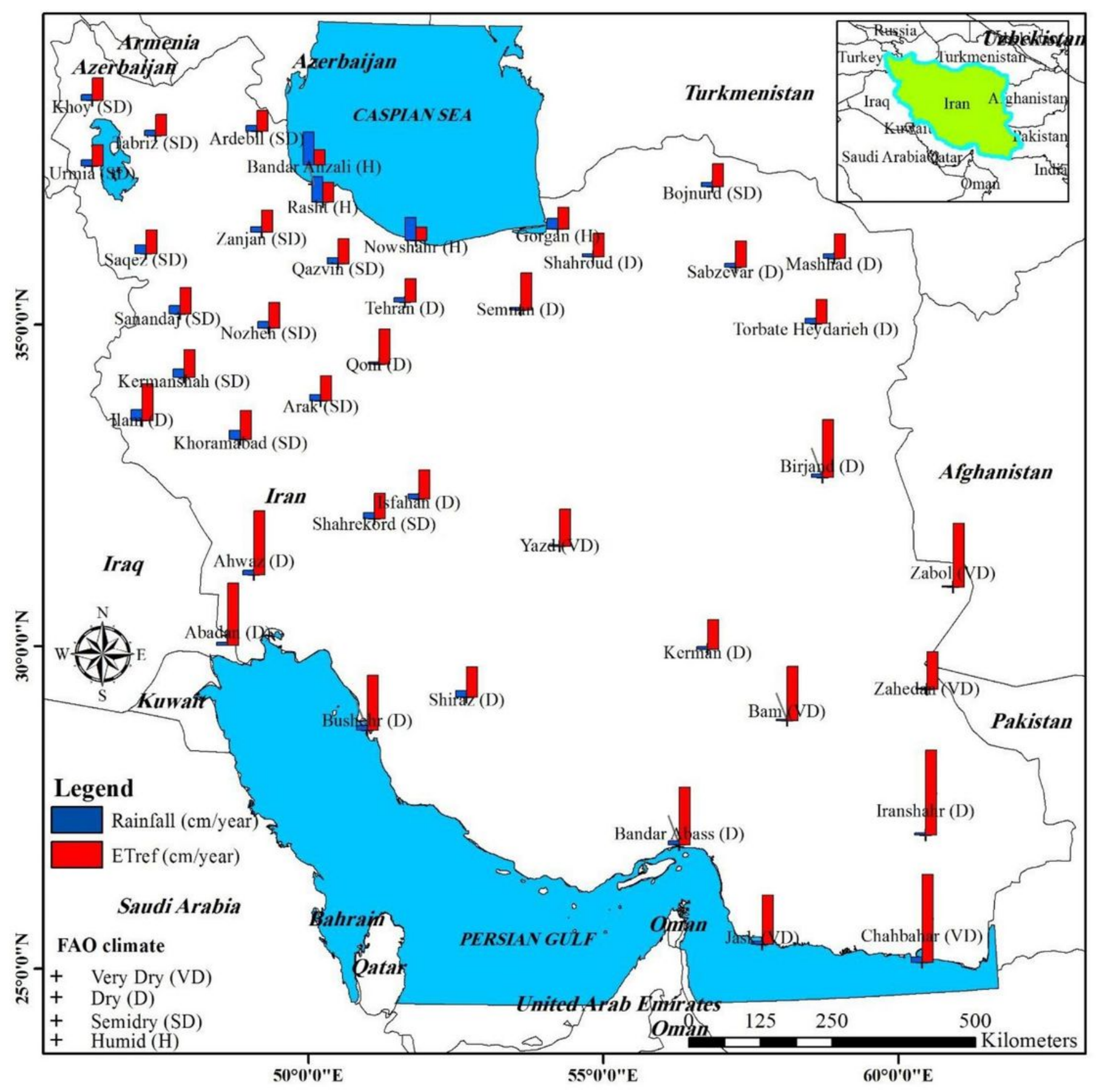

Figure 1

Location and classification of studied stations based on the FAO56 method Note: The designations employed and the presentation of the material on this map do not imply the expression of any opinion whatsoever on the part of Research Square concerning the legal status of any country, territory, city or area or of its authorities, or concerning the delimitation of its frontiers or boundaries. This map has been provided by the authors. 
(a) $\curvearrowright-\circ$ Humid $\square-\infty$ Semidry $\curvearrowright \diamond$ Dry $\triangle \Delta \triangleleft$ Very dry - Mean long-term
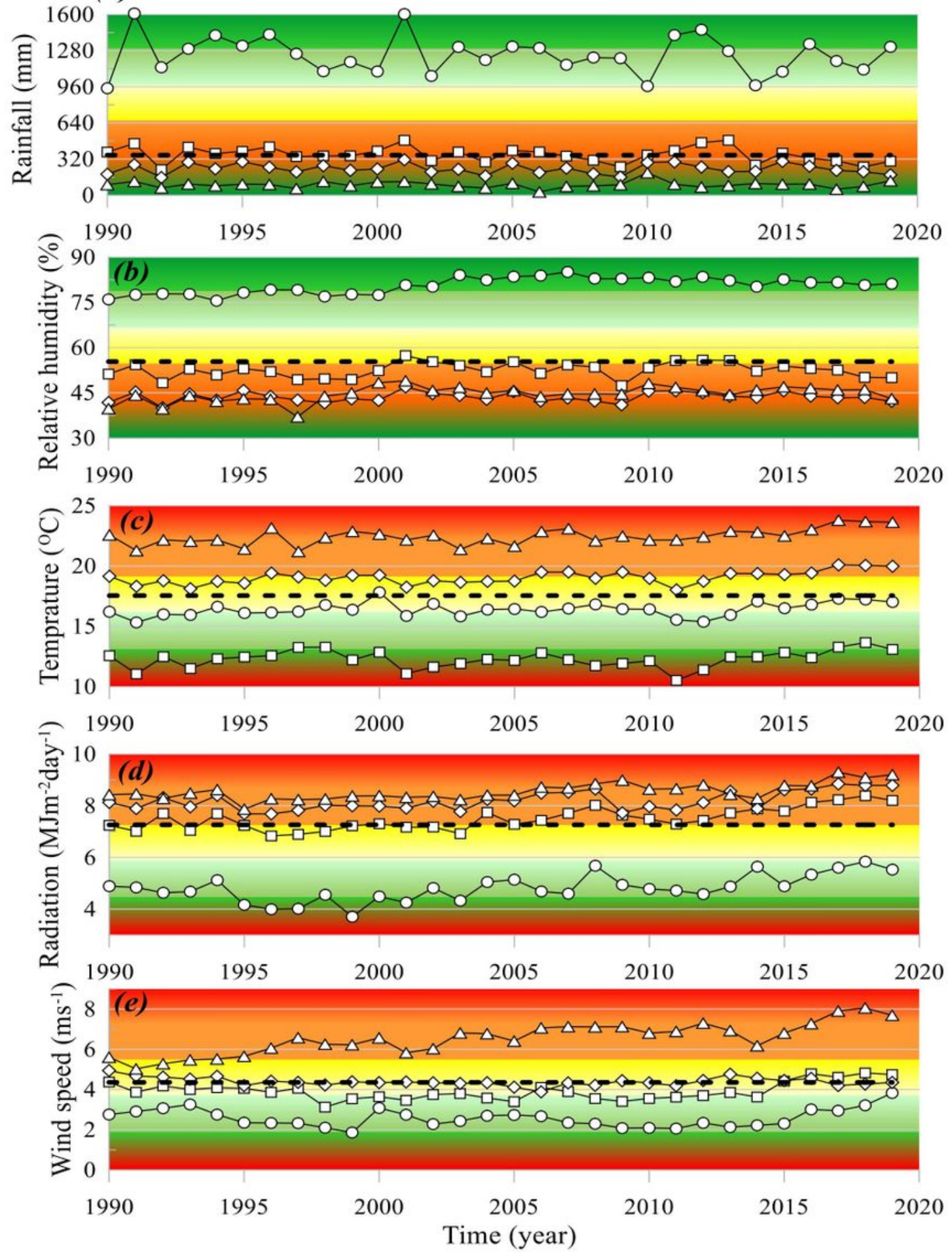

\section{Figure 2}

The long period values of a) rainfall, b) relative humidity, c) temperature, d) solar radiation and e) wind speed of Iran's climate (1990-2019) 

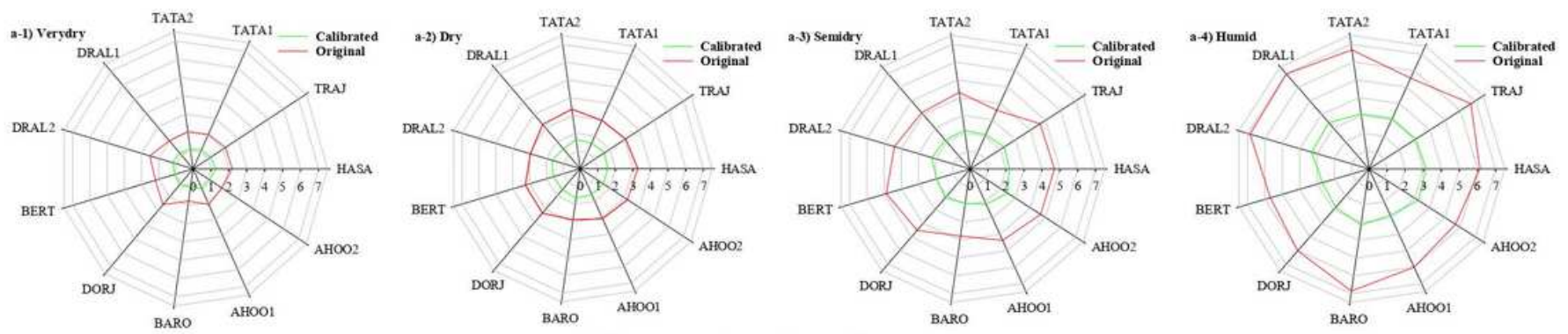

a) Temperature-based equations
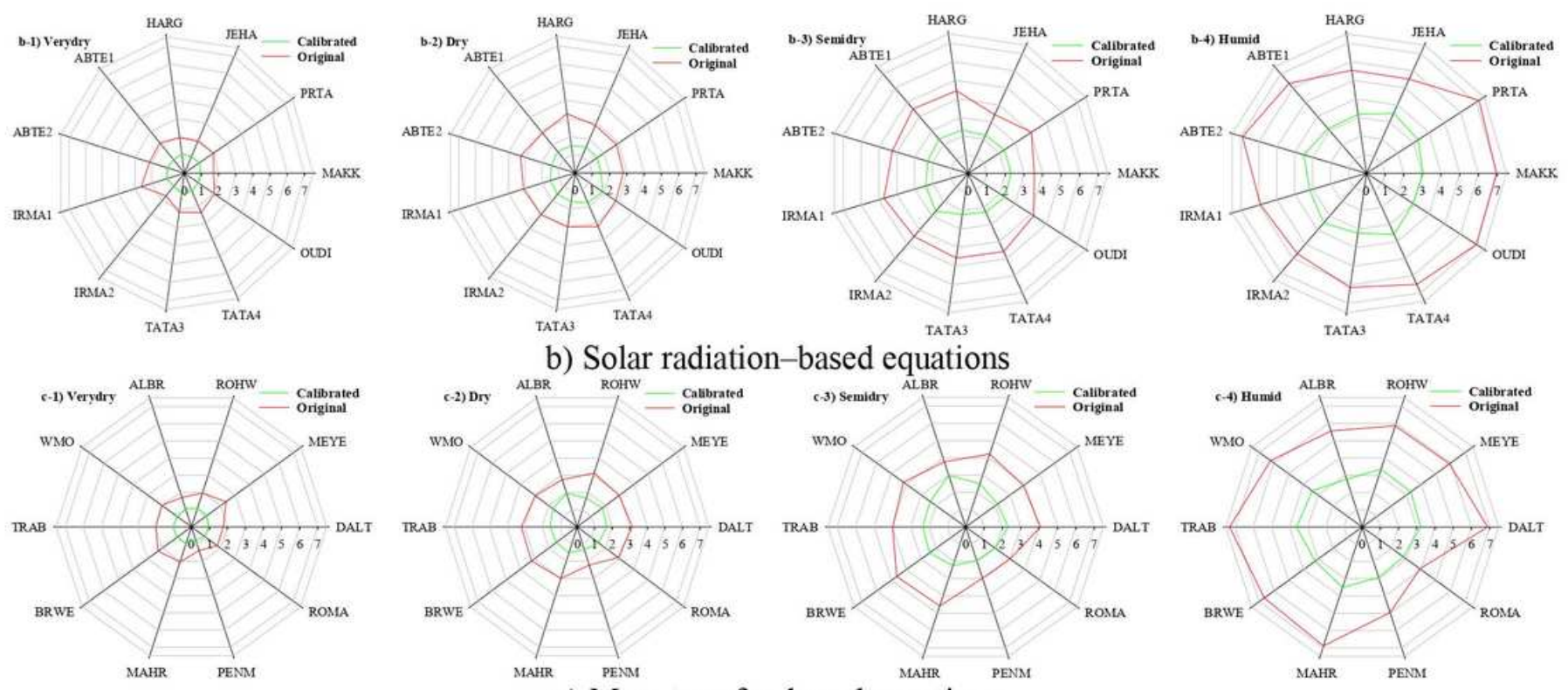

c) Mass transfer-based equations

\section{Figure 3}

The APE performance of original and calibrated empirical equations in different climates 

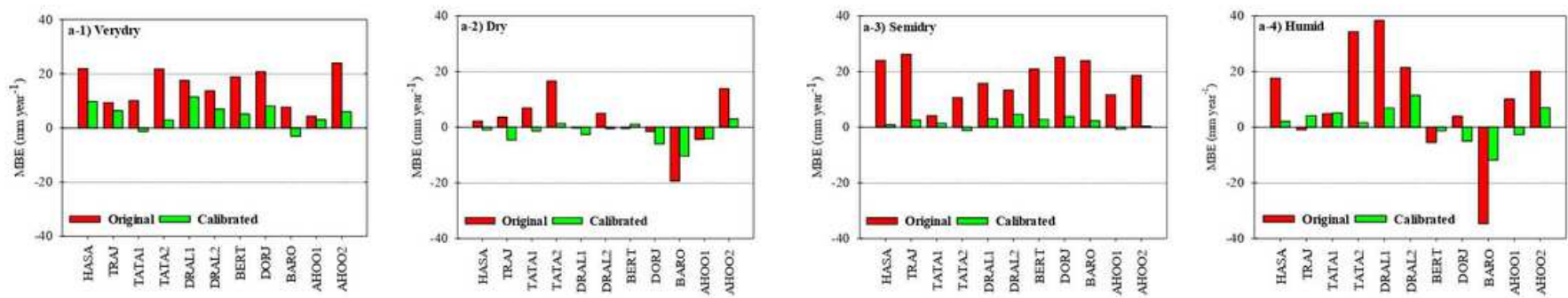

a) Temperature-based equations
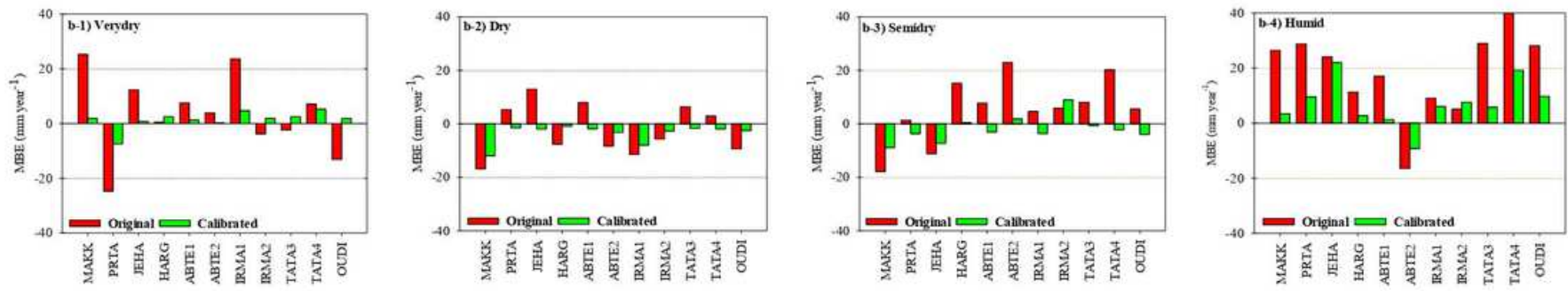

b) Solar radiation-based equations
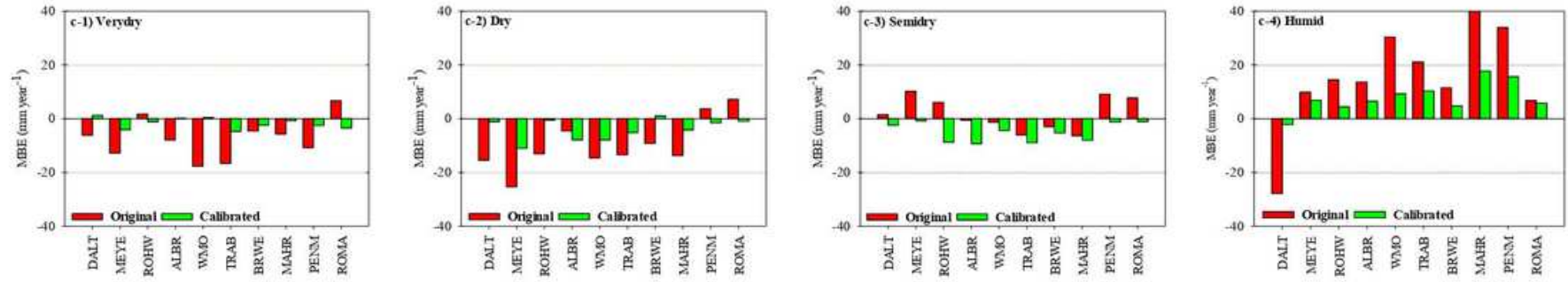

c) Mass transfer-based equations

\section{Figure 4}

The MBE performance of original and calibrated empirical equations in different climates 

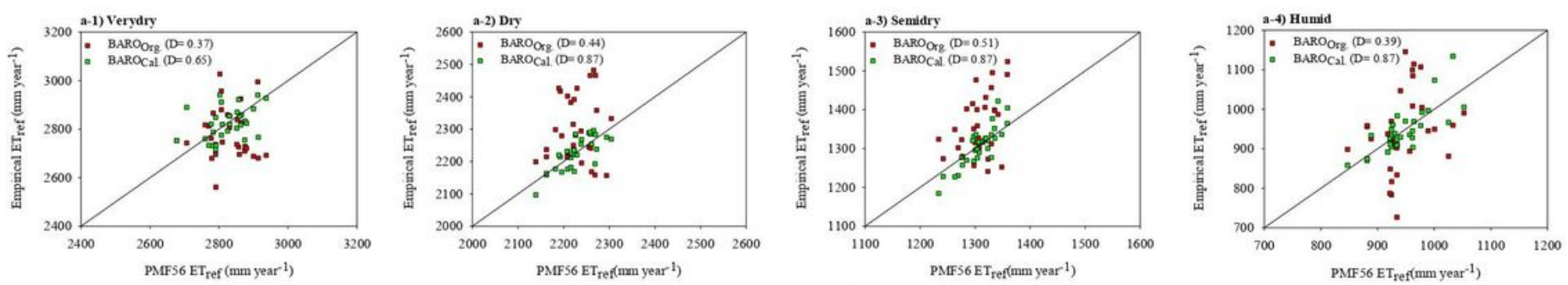

a) Temperature-based equations
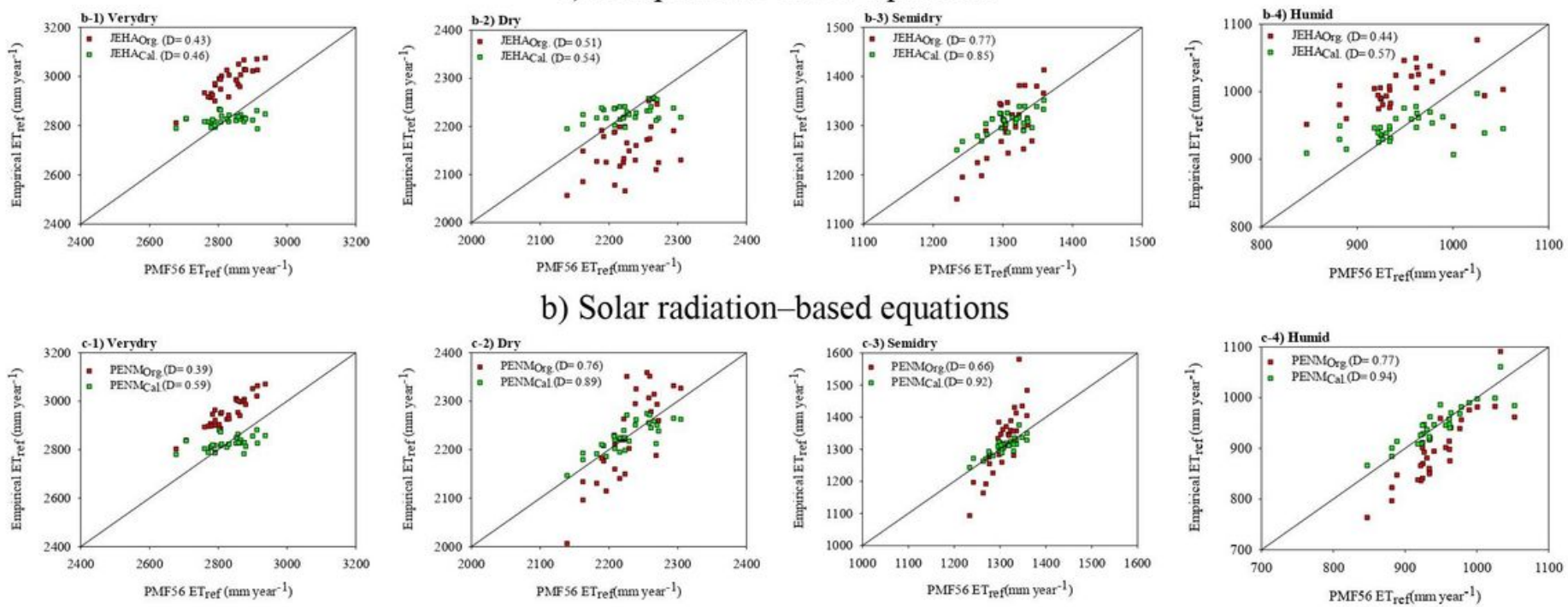

c) Mass transfer-based equations

\section{Figure 5}

The D performance of original and calibrated empirical equations in different climates 

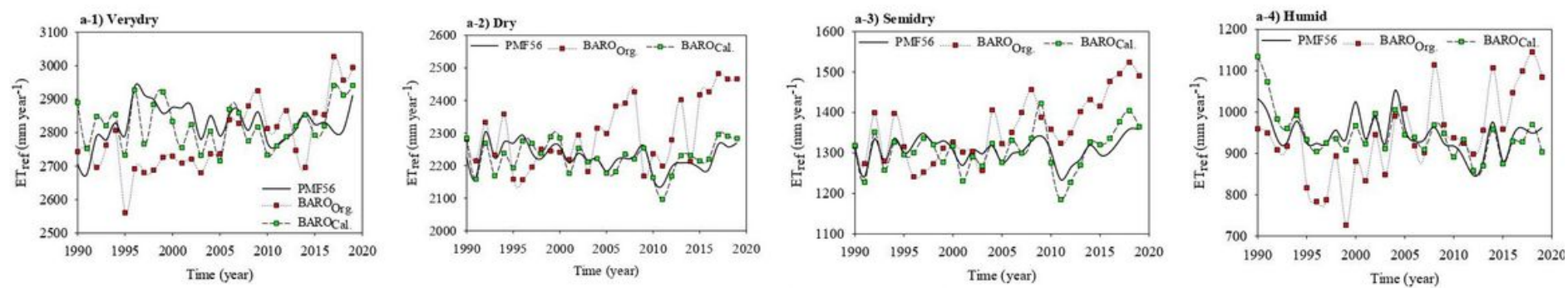

a) Temperature-based equations
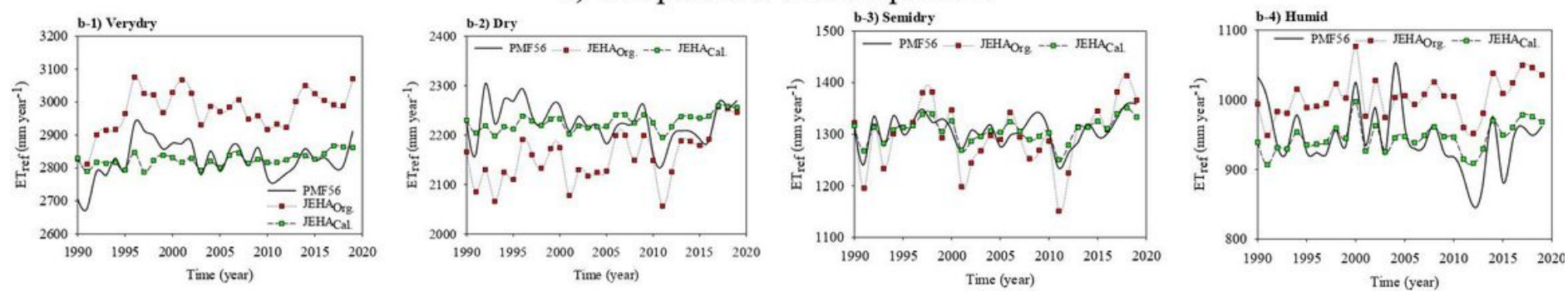

b) Solar radiation-based equations
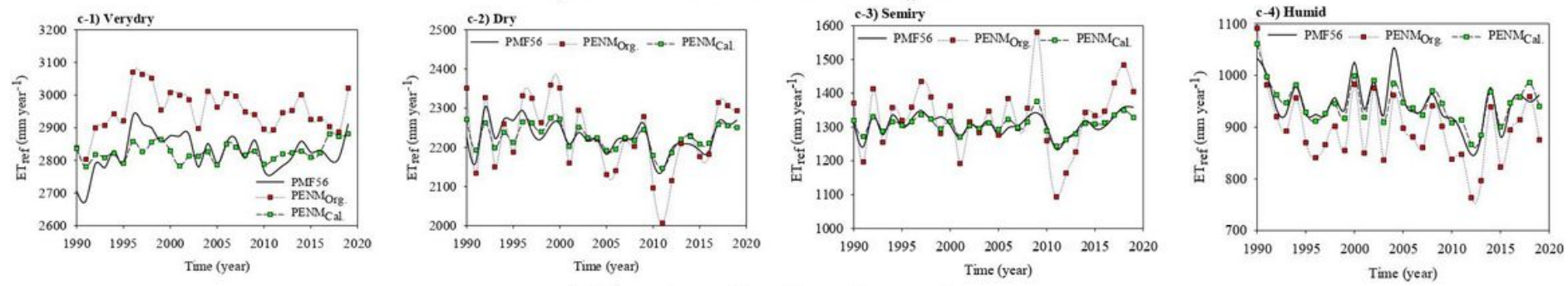

c) Mass transfer-based equations

\section{Figure 6}

The estimated ETref versus PM-FA056 values in different climates 


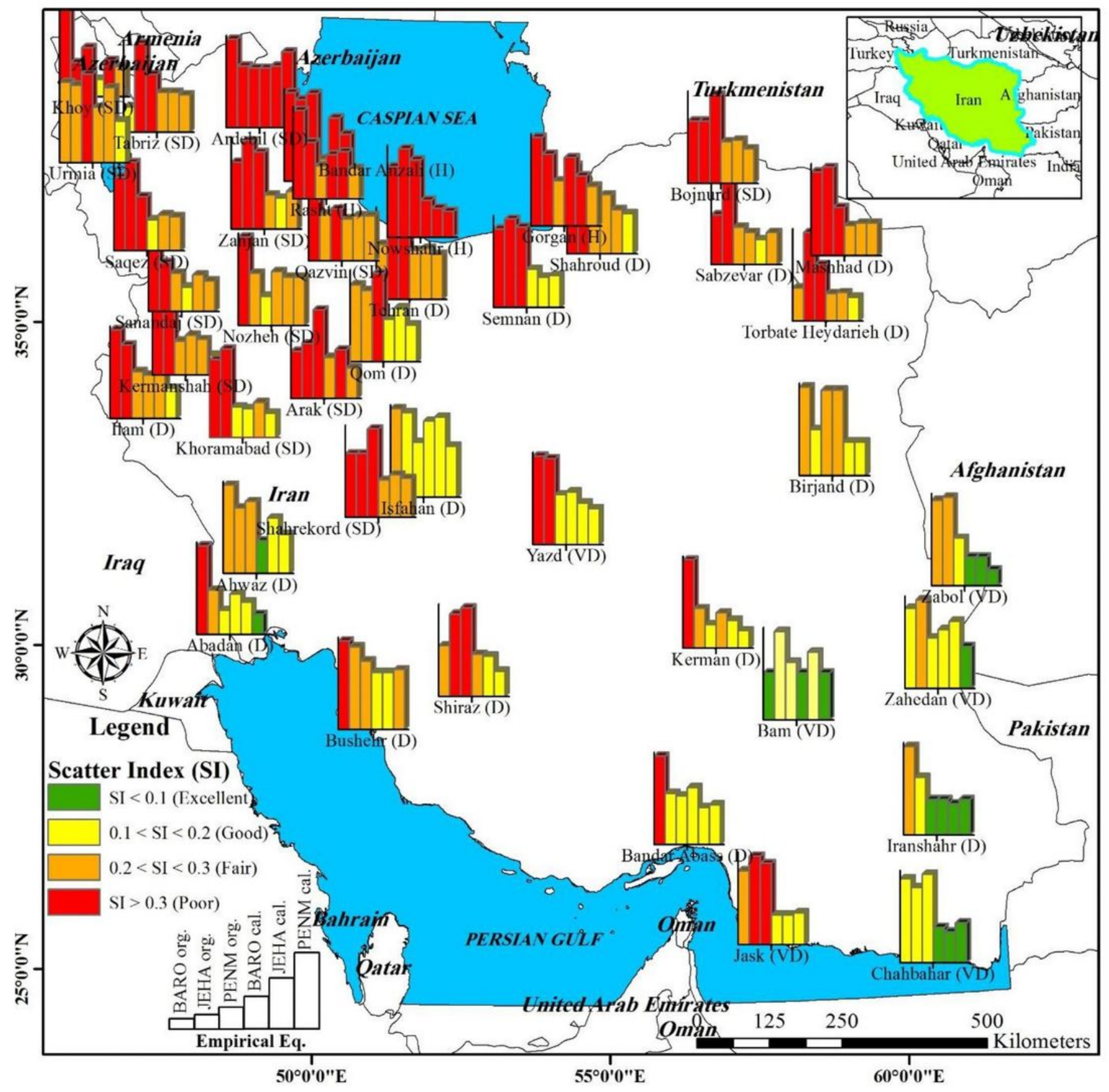

Figure 7

SI map of the best empirical equations in different climates Note: The designations employed and the presentation of the material on this map do not imply the expression of any opinion whatsoever on the part of Research Square concerning the legal status of any country, territory, city or area or of its authorities, or concerning the delimitation of its frontiers or boundaries. This map has been provided by the authors. 